\title{
COLISÃO DE DIREITOS FUNDAMENTAIS: FORMAS DE SOLUÇÃO E O POSICIONAMENTO DO SUPREMO TRIBUNAL FEDERAL
}

\section{DISSERTAÇÃO}

BOSSAK, Jeniffer Codognos ${ }^{1}$

PEGHINI, Cesar Calo ${ }^{2}$

BOSSAK, Jeniffer Codognos. PEGHINI, Cesar Calo. Colisão de direitos fundamentais: Formas de solução e o posicionamento do Supremo Tribunal Federal. Revista Científica Multidisciplinar Núcleo do Conhecimento. Ano 05, Ed. 06, Vol. 05, pp. 117-153. Junho de 2020. ISSN: 2448-0959, Link de acesso: https://www.nucleodoconhecimento.com.br/lei/colisao-de-direitos

\section{RESUMO}

O objetivo do presente estudo é analisar sobre o tema proposto, qual seja, a colisão de direitos fundamentais e a posição do Supremo Tribunal Federal. Procurou-se abordar como se soluciona um conflito entre dois direitos fundamentais, aplicando em especial a técnica da ponderação, bem como a posição do Pretório Excelso Brasileiro, a respeito do assunto. A metodologia utilizada foi através de estudo comparativo de casos e dados secundários através da utilização de vasto campo bibliográfico. $\mathrm{O}$ principal foco do trabalho é compreender como funciona a solução de um conflito entre direitos fundamentais, tendo em vista que normalmente estes direitos são consagrados na Constituição Federal e possuem status de clausula pétrea, tendo o

\footnotetext{
${ }^{1}$ Pós-graduada em Direto Constitucional e Administrativo, pela Universidade Estácio de Sá; Bacharel em Direito, Graduada no Centro Universitário Integrado - Campo Mourão/PR.

2 Doutorado em Direito. Mestrado em Função Social do Direito. Especialização em Especialista em Direito do Consumidor. Especialização em LLM em Direito Civil. Especialização em Direito Civil e Processo Civil. Graduação em Direito.
} 
mesmo valor, por este motivo a orientação é que diante de um eventual conflito desta espécie e levando em conta a carga axiológica destes preceitos os tribunais, em especial o Supremo Tribunal Federal, vem aplicando a teoria da ponderação, levando sempre em conta o princípio da proporcionalidade, portanto, há em verdade, a colocação em uma balança imaginaria destes direitos fundamentais, decidindo ao final do caso qual deve prevalecer sobre o outro. O tema, possui muita relevância, razão pela qual é de extrema importância debatê-lo, visto que, a tendência, quando chega ao Judiciário um conflito entre direitos dessa índole é tentar ao máximo salvaguardar estes direitos, afetando-os ou desvalorizando-os o mínimo possível.

Palavras-Chaves: Direitos fundamentais, colisão, princípio, Supremo Tribunal Federal.

\section{INTRODUÇÃO}

Os direitos fundamentais são os direitos humanos positivados em uma Constituição Federal de uma determinada sociedade e constituem a base de um ordenamento jurídico, tendo em vista este grau de importância que é conferido a estes direitos, visto que, são preceitos que foram construídos ao longo de toda a história do mundo, fruto de reinvindicações e lutas contra o alvedrio estatal, portanto quando há uma colisão entre eles é necessário fazer uma análise minuciosa a respeito de qual deverá prevalecer.

O presente estudo tem por finalidade realizar justamente está analise que é feita em casos de conflito entre direitos fundamentais. Em um primeiro momento estuda-se a conceituação e a problemática sobre a nomenclatura que envolve os direitos fundamentais, concluindo-se que a melhor terminologia a ser empregada é "direitos fundamentais", conforme dispõe Gregorio Martínez Peces-Barba, pois para ele constitui um conceito mais preciso e menos ambíguo que a expressão direitos humanos.

Ainda dentro da parte introdutória do desenvolvimento do trabalho, estuda-se as características dos direitos fundamentais, e uma delas tem relevante importância, que 
é a relatividade ou limitabilidade, segundo o qual, estes direitos não são absolutos, podem ser relativizados, mas nunca suprimidos, razão pela qual, é possível conferir uma carga valorativa maior a um, do que para o outro.

Pesquisa-se ainda a respeito da classificação destes direitos, mais especificamente a classificação dos direitos fundamentais dentro da visão de Karel Vasak, idealizador das três dimensões de direitos. Estuda-se ainda a eficácia dos direitos fundamentais na visão de alguns doutrinadores respeitados, como Ruy Barbosa, José Afonso da Silva e Maria Helena Diniz, finalizando o primeiro tópico com a aplicabilidade destes direitos, os quais, diga-se de passagem, possuem aplicabilidade direta e imediata, segundo dispõe a própria Constituição da República Federativa do Brasil, promulgada em 05 de outubro de 1988.

O segundo capitulo, trata da distinção entre regras e princípio segundo Ronald Dworkin e Robert Alexy, ambos estudiosos foram primordiais no estudo a respeito desta diferença entre estas espécies de normas. Chega-se ao debate a respeito da natureza jurídica dos direitos fundamentais, entendendo que possuem natureza hibrida, podendo ser tanto regra como princípio. Analisa-se, ainda, as modalidades de colisão entre os direitos fundamentais, expondo as possíveis formas de solução destes conflitos.

Por sua vez, o terceiro capítulo diz respeito as formas de solução da colisão entre os direitos fundamentais, através da aplicação dos princípios da unidade da constituição, da concordância prática e da proporcionalidade, este último calcado na técnica da ponderação, verifica-se, também, a posição dos tribunais brasileiros, os quais aplicam, comumente, o último princípio - o da proporcionalidade - bem como a ponderação na análise de casos concretos a respeito de conflitos desta índole.

Por fim, chega-se ao último capítulo da presente monografia, analisando três casos concretos que foram julgados pelo Supremo Tribunal Federal e que foram aplicada o princípio da proporcionalidade e técnica da ponderação, trata-se do confronto entre a liberdade de imprensa e a dignidade humana; a integridade física e o reconhecimento da paternidade; e a dignidade humana e o direito à vida no caso dos anencefálicos. 
Sendo assim, o escopo do presente trabalho, é demonstrar através de uma análise macro das teorias uma exemplificação, com a amostra de casos práticos, onde em um caso concreto, chegou-se à solução deste conflito através da técnica da ponderação com aplicação do princípio da proporcionalidade.

\section{COLISÃO DE DIREITOS FUNDAMENTAIS E A POSIÇÃO DO SUPREMO TRIBUNAL FEDERAL}

\subsection{CONCEITUAÇÃO DOS DIREITOS FUNDAMENTAIS}

Há na doutrina uma grande controvérsia acerca da terminologia correta a ser utilizada quando se refere à direitos fundamentais, pois confunde-se direitos humanos, com os fundamentais e muitas vezes a uma mescla entre os mesmos, além do mais a doutrina emprega várias expressões, como direitos naturais, direitos humanos, direitos do homem, direitos individuais, direitos fundamentais do homem, por está razão necessário se faz distinguir alguns conceitos.

Primeiramente os direitos naturais trata-se de direitos inerentes à natureza do homem, que cabe a eles pelo simples fato de serem homens, são direitos positivos, que possui fundamento nas relações sociais e materiais de cada momento histórico[3]. Já os direitos humanos, termo preferido nos documentos internacionais, ou também direitos do homem, são conforme ensina Mazzuoli:

a) Direitos do homem. Trata-se de expressão de cunho jusnaturalista que conota a série de direitos naturais (ou seja, ainda não positivados) aptos à proteção global do homem e válidos em todos os tempos. São direitos que, em tese, ainda não se encontram nos textos constitucionais ou nos tratados internacionais de proteção. Contudo, nos dias atuais, salvo raros exemplos, é muito difícil existir uma gama significativa de direitos conhecíveis que ainda não constem de algum documento escrito, quer de índole interna ou internacional.[4] 
Os direitos individuais consideram o indivíduo de forma isolada, a doutrina não gosta muito deste termo e a tendência é a sua não utilização, mas ainda é empregada para denotar o grupo de direitos fundamentais correspondente aos direitos civis, como a vida, igualdade, liberdade, segurança e propriedade[5].

Finalmente, os direitos fundamentais do homem, trata-se da expressão mais adequada e é a que se utiliza no presente estudo, Mazzuoli a conceitua como:

b) Direitos fundamentais. Trata-se de expressão afeta à proteção interna dos direitos dos cidadãos, ligada aos aspectos ou matizes constitucionais de proteção, no sentido de já se encontrarem positivados nas Cartas Constitucionais contemporâneas. São direitos garantidos e limitados no tempo e no espaço, objetivamente vigentes numa ordem jurídica concreta. Tais direitos devem constar de todos os textos constitucionais.[6]

Logo, é importante realizar esta pequena distinção entre as terminologias, visto que apesar de serem parecidas e comumente confundidas, não dizem respeito ao mesmo conceito.

Feita estas distinções, a nomenclatura mais correta, portanto, é direitos fundamentais, notadamente em virtude de estar em um Estado Democrático e Social de Direito e por ser o termo empregado pela Constituição Federal de 1988[7]. Seguindo a mesma linha a respeito da nomenclatura correta, Gregorio Martínez Peces-Barba em seu livro: curso de derechos fundamentales: teoría general, expõe as razões do porquê "direitos fundamentais" é o melhor termo a ser empregado:

a) São mais precisos e menos ambíguos que a expressão direitos humanos. b) pode abarcar as duas dimensões dos direitos humanos sem incorrer em reducionismos jus naturalistas ou positivistas [...]. c) É mais adequada que as expressões "direitos naturais" ou "direitos morais" que mutilam os direitos humanos de sua faceta positiva. [...] d) É mais 
adequada que a expressão "direitos públicos subjetivos" ou "liberdades públicas" que podem perder de vista a dimensão moral [...].[8]

Convém demonstrar ainda, a visão de Gregório Peces-Barba Martínez, ao conceituar os direitos fundamentais, entendendo que se trata de uma pretensão moral, visando facilitar a independência das pessoas:

Una pretensión moral justificada, tendente a facilitar la autonomía y la independencia personal, enraizada en las ideas de libertad y igualdad, con los matices que aportan conceptos como solidariedad y seguridad jurídica, y construida por la reflexión racional en la historia del mundo moderno, con las aportaciones sucesivas e integradas de la filosofía moral y política liberal, democrática y socialista.[9]

Portanto, os direitos fundamentais constituem exemplos de direitos humanos positivados na legislação vigente em determinada sociedade, que garantem direitos básicos a todas as pessoas, para terem uma vida com dignidade.

\subsection{CARACTERÍSTICAS DOS DIREITOS FUNDAMENTAIS}

Os direitos fundamentais, conforme visto, foram nascendo e moldando-se ao longo do tempo, por isso é difícil elencar acertadamente as características que estes direitos possuem, no entanto, a doutrina relaciona uma série de atributos inerentes aos direitos fundamentais, que serão analisados abaixo.

A primeira delas é a historicidade, como o próprio nome sugere, os direitos fundamentais decorrem de uma evolução histórica, conforme as civilizações foram se desenvolvendo, aqueles foram acompanhando, se desdobrando e até concebendo novos direitos. Outra característica apontada pela doutrina é a universalidade, isto é, os direitos fundamentais destinam-se a todas as pessoas, independentemente de qualquer perfil, raça, gênero, etc.

São considerados relativos ou limitados, isto quer dizer que não são absolutos, por isso que em um eventual conflito entre eles, um poderá ser relativizado frente a 
outro[10], inclusive o próprio Supremo Tribunal Federal deixa claro em suas decisões que os direitos fundamentais não possuem caráter absoluto, entretanto, entende também que estes direitos possuem limites que devem ser respeitados[11].

Os direitos fundamentais, também são concorrentes, razão pela qual podem ser exercidos simultaneamente[12]. São ainda invioláveis, pois a legislação infraconstitucional não poderá desrespeitá-lo; é inalienável, sendo impossível sua transmissão seja a qualquer título; imprescritíveis, quer dizer que não se perdem pelo decurso do tempo e irrenunciáveis, o seu titular pode não os usá-los, mas nunca poderá renuncia-Ihes[13].

\subsection{DIMENSÕES DE DIREITOS FUNDAMENTAIS NA VISÃO DE KAREL VASAK}

Haja vista toda a evolução que os direitos fundamentais passaram ao longo de sua história, pelo interior de lutas e reinvindicações até a sua final positivação, para que fosse necessário a manutenção de uma vida digna; a partir do exposto Karel Vasak, na conferencia proferida em 1979, no Instituto Internacional de Direitos Humanos em Estraburgo, firmou, corretamente, a ideia de evolução dos direitos humanos e fundamentais, os quais podem ser compreendidas a partir da identificação de três "gerações" de direitos[14], cada uma com características próprias e posteriormente, outros autores defenderam a ampliação dessa classificação para quatro ou até cinco gerações.

Vazak associou cada geração de direitos fundamentais, a um dos componentes do dístico da Revolução Francesa: "liberté, egalité et fraternité" (liberdade, igualdade e fraternidade), ressalta-se que essas gerações não se excluem, mas se complementam[15].

Os direitos de primeira geração são aqueles que buscam restringir a atuação estatal sobre o indivíduo, são também denominados de liberdades negativas, possuem como valor-fonte a liberdade, a respeito desta geração Pedro Lenza vaticina que: 
Os direitos humanos da 1. a dimensão marcam a passagem de um Estado autoritário para um Estado de Direito e, nesse contexto, o respeito às liberdades individuais, em uma verdadeira perspectiva de absenteísmo estatal. Seu reconhecimento surge com maior evidência nas primeiras Constituições escritas, e podem ser caracterizados como frutos do pensamento liberal-burguês do século XVIII. Tais direitos dizem respeito às liberdades públicas e aos direitos políticos, ou seja, direitos civis e políticos a traduzir o valor liberdade.[16]

Por sua vez, os direitos de segunda geração, diferentemente dos de $1^{\circ}$ dimensão, envolvem prestações positivas do Estado, possuem como valor-fonte a igualdade, conforme ensina Gilmar Mendes:

O princípio da igualdade de fato ganha realce nessa segunda geração dos direitos fundamentais, a ser atendido por direitos a prestação e pelo reconhecimento de liberdades sociais - como a de sindicalização e o direito de greve. Os direitos de segunda geração são chamados de direitos sociais, não porque sejam direitos de coletividades, mas por se ligarem a reivindicações de justiça social - na maior parte dos casos, esses direitos têm por titulares indivíduos singularizados.[17]

Já os direitos de terceira geração acabam transcendendo a órbita individual alcançando a coletividade, são os transindividuais ou supraindividuais, possuem como valor-fonte a fraternidade, sobre eles preconiza Walber de Moura Agra:

Os direitos de terceira dimensão têm como principal vetor o direito à fraternidade, fraternidade de direitos do gênero humano. São exemplos típicos de prerrogativas de terceira dimensão: direito ao desenvolvimento, à paz, ao meio ambiente equilibrado, ao patrimônio histórico, artístico e cultural, à autodeterminação dos povos, à solidariedade, ao desenvolvimento, à proteção dos consumidores, direitos dos hipossuficientes, à preservação da intimidade etc. Também são denominados direitos pós-materiais. [...] Os sujeitos da relação dos 
direitos de terceira dimensão não são mais o cidadão-cidadão ou o cidadão Estado - a titularidade passa a ser difusa, coletiva, transindividual. $O$ destinatário é o homem em termos de gênero humano, enfocado sob um prisma coletivo. Se o destinatário é coletivo, a responsabilidade para a sua concretização também é coletiva, não dependendo apenas da atuação estatal para assegurar a todos a consecução desses direitos. $O$ cidadão tem especial participação na sua efetivação.[18]

Há ainda, doutrinadores que defendam a existência de direitos de $4^{\circ}$ e $5^{\circ}$ gerações. Nesse sentido, Noberto Bobbio entende que os direitos de quarta geração se referem à engenharia genética, ensinando que: "[...] chamar-se de direitos de quarta geração, referentes aos efeitos cada vez mais traumáticos da pesquisa biológica, que permitirá manipulações do patrimônio genético e cada indivíduo"[19].

Com outro ponto de vista, Paulo Bonavides afirma que os direitos de quarta geração referem-se: à globalização, à democracia, informação e ao pluralismo; trata-se da ação de uma civitas máxima, dispondo o seguinte: "a globalização política na esfera da normatividade jurídica introduz os direitos da quarta dimensão, que, aliás, correspondem à derradeira fase de institucionalização do Estado social"[20], o mesmo ainda entende que o direito a paz deve ser tratado como de $5^{\circ}$ geração, afirmando que a paz é axioma da democracia participativa, ou, ainda, supremo direito da humanidade.[21]

\subsection{EFICÁCIA DOS DIREITOS FUNDAMENTAIS}

Sabe-se que a Constituição Federal de 1988 foi promulgada após um grande período marcado pela supressão ou ausência de direitos por conta da ditadura militar, por esta razão na Carta Política vigente foi criado um extenso catálogo de direitos fundamentais, dispostos em especial em seu título II, englobando os direitos e deveres individuais e coletivos, os direitos sociais, direitos de nacionalidade e direitos políticos. 
Outro ponto que convém explanar é que as normas constitucionais, e dentro disso, os próprios direitos fundamentais possuem variados graus de eficácia e aplicabilidade de acordo com a normatividade que Ihes tenha sido outorgada e este fato fez com que alguns estudiosos elaborassem classificações acerca da eficácia dessas normas.

A primeira classificação foi a proposta por Ruy Barbosa que se inspirou na doutrina norte-americana e dividia as normas constitucionais em dois grupos: normas autoexecutáveis, na qual os preceitos constitucionais são completos e produzem seus plenos efeitos com a simples entrada em vigor e normas não autoexecutáveis, que são indicadoras de princípios, que necessitam de atuação legislativa posterior, para Ihe dar plena aplicação[22].

Posteriormente, surgiu a classificação tricotômica de José Afonso da Silva, baseado na doutrina italiana de Vezio Crusafulli[23], segundo ele há três categorias de normas, sendo estas: normas constitucionais de eficácia plena, normas de eficácia contida e normas de eficácia limitada.

As normas de eficácia plena são aquelas dotadas de aplicabilidade direta, imediata e integral, que desde a entrada em vigor da Constituição, produzem, ou tem possibilidade de produzir todos os efeitos essenciais, não exigindo a elaboração de novas normas legislativas que thes complementem, por isso são normas de aplicabilidade direta, imediata e integral.[24]

Já, as normas de eficácia contida que são aquelas em que o legislador regulou suficientemente os interesses relativos a certa matéria, mas deixou certa margem de atuação restritiva por parte do Poder Público, são normas de aplicabilidade direta, imediata, mas não integral, visto que são sujeitas a restrições posteriormente impostas.[25] Estas se dividem em normas de eficácia limitada de princípio programático - são normas que regulam diretamente direitos, mas limitam-se a traçar preceitos a serem cumpridos pelo poder público - e normas de eficácia limitada de princípio institutivo - que são responsáveis pela estruturação do Estado.[26] 
Há ainda, as normas em eficácia limitada, que são aquelas que não produzem, com a simples entrada em vigor, os seus efeitos essenciais, pois o legislador não estabeleceu uma normatividade, deixando essa tarefa ao outro órgão ou legislador, possui aplicabilidade indireta, mediata e reduzida, já que só incidem totalmente a partir de uma normatização infraconstitucional ulterior.[27]

Seguindo a mesma ideia de que José Afonso da Silva, a doutrinadora Maria Helena Diniz também classificou as normas constitucionais, dividindo-as em quatro grupos. Primeiro tem as normas super eficazes ou com eficácia absoluta que são dotadas de efeito paralisante de toda a legislação infraconstitucional incompatível, sendo normalmente designadas pela doutrina como cláusulas pétreas. Existe também as normas de eficácia plena as quais desde sua edição possui os elementos necessários a integral produção dos seus efeitos, dispensando regulamentação posterior. As normas de eficácia restringível são as que admitem legislação integradora que venha restringir o seu alcance. Enfim, as normas de eficácia relativa complementável, são as que seus efeitos dependem de regulamentação integradora.[28]

Outra classificação usualmente aceita é a dos estudiosos Celso Ribeiro Bastos e Carlos Ayres Britto, para eles essa classificação refere-se à vocação das normas para atuação ou não do legislador. Assim, classificam em normas constitucionais de aplicação, que são aquelas que não necessitam de atuação do legislador, e normas constitucionais de integração, que são aquelas que necessitam de uma atuação do legislador para produzir seus efeitos, esta última divide-se em normas constitucional de integração complementáveis, as quais requerem uma atuação do poder público para produzir seus efeitos plenamente e normas constitucionais de integração restringíveis, que são aquelas que podem sofrer restrição por parte do legislador infraconstitucional.[29]

Ainda há a classificação proposta pelo Ministro Luís Roberto Barroso, o qual dividiu em três grupos: normas constitucionais definidoras de direitos, que tem por objeto a previsão dos direitos e garantias fundamentais; normas constitucionais de organização que objetivam estruturar e disciplinar o exercício do poder político, dirigindo-se ao Poder e seus agentes; e normas constitucionais programáticas, que 
estabelecem finalidades para a atuação estatal[30], existem ainda outras classificações propostas por outros catedráticos, no entanto não convém aprofundar sobre o tema no presente estudo, o que importa é saber que todos os autores mencionados acima entendem que não existe norma constitucional totalmente destituída de eficácia, falando-se apenas em gradação da eficácia destas normas, pois a depender do caso a eficácia mudará, podendo ser maior, menor, complementável ou restringível.[31]

\section{DISTINÇÃO ENTRE REGRAS E PRINCÍPIOS}

Oportuno entender como é capitulado os direitos fundamentais, o debate gira em torno de sua natureza jurídica, de sua interpretação como regras ou princípios; a posição na doutrina ainda não é unânime, portanto, primeiramente é necessário se fazer distinguir os dois institutos.

Alguns autores, como Robert Alexy e Ronald Dowrkin, possuem obras respeitadíssimas sobre a diferença sobre regras e princípios, com técnicas próprias de distinções entre uns e outros[32], assim, convém analisar a opinião de cada um deles, conforme abaixo.

\subsection{DISTINÇÃO ENTRE REGRAS E PRINCÍPIOS NA VISÃO DE RONALD DWORKIN}

Ronald Dworkin é um importante autor, quando se refere a regras e princípios, ele elaborou sua tese atacando o positivismo de Herbet Hart, segundo este quando não há uma regra para aplicar-se ao caso concreto ou esta é indeterminada, o juiz deve tomar uma decisão discricionária e criar uma solução ao caso, no entanto, para Dworkin essa tese não pode ser aceita, visto que todo ordenamento jurídico é constituído por regras e princípios, razão pela qual o interprete ao se deparar com um caso, não pode tomar uma decisão discricionária, mas deve aplicar os princípios jurídicos[33]. Ensina Lenio Strek que: 
Dworkin, contrapondo-se ao formalismo legalista e ao mundo de regras positivista, busca nos princípios os recursos racionais para evitar o governo da comunidade por regras que possam ser incoerentes em princípio. É nesse contexto que Dworkin trabalha a questão dos hard cases, que incorporam, na sua leitura, em face das dúvidas sobre o sentido de uma norma, dimensões principiológicas, portanto, não consideradas no quadro semântico da regra.[34]

Sabendo, portanto, que um sistema jurídico é composto por regras e princípios, Dworkin desenvolveu dois critérios para diferenciar essas duas espécies normativas, logo a diferença entre regras e princípios é de natureza lógica[35].

O primeiro critério distintivo é que as regras atuam através do tudo-ou-nada (all-ornothing-fashion), isto é, ou a regra se aplica ao caso concreto ou não, conforme ensina Dworkin:

Os dois conjuntos de padrões apontam para decisões particulares acerca da obrigação jurídica em circunstâncias especificas, mas distinguem-se quanto á natureza da orientação que oferecem. As regras são aplicáveis à maneira do tudo-ou-nada. Dados os fatos que uma regra estipula, então ou a regra é válida, e neste caso a resposta que ela fornece deve ser aceita, ou não é válida, e neste caso em nada contribui para a decisão.[36]

Por sua vez, os princípios não possuem a mesma precisão e obrigatoriedade que as regras, assim o segundo critério é que os princípios possuem um peso ou uma importância, por esta razão em um eventual conflito entre princípios a decisão será tomada pesando os dois, aplicando aquele que possuir maior peso que o outro:

Os princípios possuem uma dimensão que as regras não têm - a dimensão do peso ou importância. Quando os princípios se intercruzam (por exemplo, a política de proteção aos compradores de automóveis se 
opõe aos princípios de liberdade de contrato), aquele que vai resolver o conflito tem de levar em conta a força relativa de cada um.[37]

Sendo assim, apesar das regras e dos princípios serem espécies de normas, em nada se parecem, pois, em um eventual conflito entre regras resolve-se aplicando uma ou outra, já em um eventual conflito entre princípios um cederá em relação ao outro e isto é o caráter distintivo entre estas normas.

\subsection{DISTINÇÃO ENTRE REGRAS E PRINCÍPIOS NA VISÃO DE ROBERT ALEXY}

Robert Alexy também desenvolveu importante estudo a respeito da distinção entre regras e princípios, para ele regras são normas que podem ser cumpridas ou não, já os princípios são mandados de otimização:

O ponto decisivo na distinção entre regras e princípios é que princípios são normas que ordenam que algo seja realizado na maior medida possível dentro das possibilidades jurídicas e fáticas existentes. Princípios são, por conseguinte, mandamentos de otimização, que são caracterizados por poderem ser satisfeitos em graus variados e pelo fato de que a medida devida de sua satisfação não depende somente das possibilidades fálicas, mas também das possibilidades jurídicas. [...] Já as regras são normas que são sempre ou satisfeitas ou não satisfeitas. Se uma regra vale, então, deve se fazer exatamente aquilo que ela exige; nem mais, nem menos. Regras contêm, portanto, determinações no âmbito daquilo que é fática e juridicamente possível. Isso significa que a distinção entre regras e princípios é uma distinção qualitativa, e não uma distinção de grau. Toda norma é ou uma regra ou um princípio.[38]

Diferentemente dos critérios propostos por Dworkin, que propunha que a diferença está no peso e importância, para a teoria alexyana a distinção está em critérios qualitativos, por isso a distinção entre regras e princípios está na forma de solução da colisão entre estas normas. 
Para ele, a colisão entre duas regras se resolverá expurgando uma regra em face a outra, isto é, aplica-se uma regra em detrimento e outra - se não for possível essa subsunção, utiliza-se os critérios "lex posterior derogat legi priori", ou "lex specialis derogat legi generali", ou "lex superior derogat legi inferior" para resolver o imbróglio; o conflito entre dois princípios é solucionada mediante a técnica da ponderação[39], todas estas formas de solução de conflito entre normas serão estudados e analisados abaixo.

Feita está pequena distinção entre regras e princípios, necessário fazer uma análise da natureza jurídica dos direitos fundamentais, entendendo se tratar de qual destas espécies normativas.

\subsection{NATUREZA JURÍDICA DOS DIREITOS FUNDAMENTAIS: PRINCÍPIOS OU REGRAS}

Conforme mencionado, o direito é formado por normas e estas se dividem em duas espécies: regras e princípios, a despeito disso Gustavo Zagrebelsky ensina que se o direito fosse formado apenas por regras seria muito mecânico e simplista:

Si el derecho sólo estuviese compuesto de reglas no sería insensato pensar em la "maquinización" de su aplicación por medio de autómatas pensantes, a los que se les porporcionaría el hecho y nos darían la respuesta. Estos autómatas tal vez podrían hacer uso de los principales esquemas lógicos para la aplicación de reglas normativas: el silogismo judicial y la subsunción del supuesto de hecho concreto en el supuesto abstracto de la norma. Ahora bien, tal idea, típicamente positivista, carece totalmente de sentido en la medida em que el derecho contenga princípios.[40]

Destarte, Gilmar Ferreira Mendes conceitua princípios como padrões que expressam exigências de justiça, com virtudes multifuncionais, diferente das regras, aquelas desempenham uma função argumentativa e seriam úteis para se descobrir a razão de ser de uma regra ou outro princípio[41]. 
Portanto, pode-se afirmar que normas se exprimem através das regras e dos princípios, o primeiro é mais genérico, utilizadas para determinadas situações concretas, já os princípios são mais abrangentes e abstratos, podendo ser utilizados para interpretar várias situações, tecidas tais considerações, conclui-se que a natureza jurídica dos direitos fundamentais pode ter caráter dúplice, tal como explica Alexy:

O fato de que, por meio das disposições de direitos fundamentais, sejam estatuídas duas espécies de normas - as regras e os princípios - é o fundamento do caráter duplo das disposições de direitos fundamentais. Mas isso não significa ainda que também as normas de direitos fundamentais compartilhem desse mesmo caráter duplo. De início elas são ou regras (normalmente incompletas) ou princípios. Mas as normas de direitos fundamentais adquirem um caráter duplo se forem construídas de forma a que ambos os níveis sejam nelas reunidos.[42]

Posto isto, julgando que os direitos fundamentais são verdadeiras normas positivadas em um ordenamento jurídico, elas poderão possuir natureza jurídica tanto de regra como de princípios a depender do contexto em que estarão inseridos, logo eventuais colisões entre estes direitos podem possuir uma série de formas de resolução de conflitos.

\section{MODALIDADES DE COLISÃO DE DIREITOS FUNDAMENTAIS}

Conforme exposto acima, os direitos fundamentais podem ter caráter dúplice, ora será princípio, ora será regra. Sendo assim, poderão surgir três formas de colisão ou conflitos entre estes direitos, a saber: colisão entre regras, colisão entre princípios e regras e a colisão entre princípios, que serão estudados a seguir. 


\subsection{COLISÃO ENTRE REGRAS}

A primeira forma de conflito existente em um ordenamento jurídico é o que ocorre entre as regras, estas são normas gerais e abstratas, criadas para resolver um conflito certo e determinado. Neste sentido ensina Robert Alexy que regras constituem:

[...] las reglas son normas que sólo pueden ser cumplidas o no. Si una regla es válida, entonces de hacerse exactamente lo que ella exige, $n i$ más ni menos. Por lo tanto, las reglas contienen determinaciones en el ámbito de lo fáctica y jurídicamente posible. Esto significa que la diferencia entre reglas y principios es cualitativa y no de grado. Toda norma es o bien una regla o un principio.[43]

Quando há uma colisão ou um conflito entre duas ou mais regras, onde ambas se encontram em posições antagônicas, dizer-se que há uma antinomia, a qual consiste na oposição entre duas normas contraditórias, emanadas da mesma autoridade competente, colocando o sujeito em uma posição desfavorável ante a ausência de meios para solucionar o conflito.[44]

A antinomia é classificada em duas espécies: a real ou lacunas de conflito e a aparente. Ocorrerá a primeira quando no ordenamento não houver qualquer modo de solucionar o conflito, senão com a edição de uma nova norma. Tércio Sampaio Ferraz Júnior ensina que a antinomia real não impede a solução do conflito:

O reconhecimento desta lacuna não exclui a possibilidade de uma solução efetiva, quer por meios ab-rogatórios (edita-se nova norma que opta por uma das normas antinômicas), quer por meio de interpretação equitativa, recurso ao costume, à doutrina, a princípios gerais do direito, entre outros. $\mathrm{O}$ fato, porém, de que estas antinomias ditas reais sejam solúveis desta forma não exclui a antinomia, mesmo porque qualquer das soluções, ao nível da decisão judiciária, pode suprimi-la no caso concreto, mas não suprime a sua possibilidade no todo do ordenamento, inclusive no caso de edição de nova norma, que pode por pressuposição, 
eliminar uma antinomia e, ao mesmo tempo dar origem a outras. O reconhecimento de que há antinomias reais indica, por fim, que o direito não tem o caráter de sistema lógico-matemático, pois sistema pressupõe consistência, o que a presença da antinomia real exclui.[45]

Por sua vez a antinomia aparente acontece quando em um caso, havendo um conflito entre duas regras, há possibilidade de aplicação de certos critérios e/ou normas integrantes, conforme ensina Maria Helena Diniz:

[...] antinomia aparente, se os critérios para a solucionar forem normas integrantes de ordenamento jurídico; e antinomia real, se não houver na ordem jurídica qualquer critério normativo para sua solução, sendo, então, imprescindível para sua eliminação, a edição de uma nova norma.[46]

Em uma eventual colisão entre duas regras, a solução a ser buscada é através da subsunção da norma, isto quer dizer que uma das normas será aplicada e a outra expurgada, caso isso não seja possível, haverá então uma antinomia aparente que pode ser solucionada através da aplicação de três critérios: o hierárquico, o cronológico e o de especialidade.

O primeiro critério a ser aplicado é o hierárquico, onde "um conflito entre normas de diferentes níveis, a de nível mais alto, qualquer que seja a ordem, cronológica, terá preferência em relação à de nível mais baixo"[47], isto é, lex superior derogat legi inferior.

O segundo critério é o cronológico, neste o conflito encontra-se em duas normas de mesma hierarquia, razão pela qual resta impossível usar o primeiro critério, então usar-se-á a máxima da "lex posterior derogat legi priori", ou seja, lei posterior derroga lei anterior.

O terceiro e último critério é o da especialidade, segundo o qual "lex specialis derogat legi gnerali", isto é, se as normas conflitantes forem uma geral e outra especial, prevalece a segunda, visto que geralmente está "possui em sua definição legal todos 
os elementos típicos da norma geral e mais alguns de natureza objetiva ou subjetiva, denominados especializantes"[48]

Caso não seja possível a aplicação de nenhum destes critérios elencados acima, então estar-se-á diante de uma antinomia real, a qual poderá ser solucionada através da criação de uma nova norma.

\subsection{COLISÃO ENTRE PRINCÍPIOS E REGRAS}

A colisão entre um princípio constitucional e uma regra, pode ocorrer de formas diferentes, a depender do grau e conteúdo que possui está regra e este princípio. Se a regra e o princípio possuírem o mesmo nível hierárquico, prevalecerá aquele, conforme ensina Thomas Bustamante:

Conflito (em sentido estrito) [...] entre um princípio e uma regra de mesmo nível hierárquico) é normalmente solucionada pelo predomínio da regra sobre o princípio de igual hierarquia com o qual ela venha a colidir. A pretensão de definitividade que está presente nas regras jurídicas se manifesta em seu grau máximo, pois o mesmo legislador que escolheu os princípios jurídicos vinculantes para o caso concreto estabeleceu também uma prioridade entre esses princípios no caso coberto pela regra. A existência de uma regra implica, em si mesma, uma decisão sobre a prioridade entre princípios colidentes.

Por seu turno, se o princípio for constitucional colidindo com uma regra infraconstitucional, sendo aquele de maior hierarquia, prevalecerá o princípio, pois "a violação de um princípio passa a ser mais grave que a transgressão de uma regra jurídica"[49], já que desrespeitar um princípio constitucional ensejará em "uma ruptura da própria Constituição"[50], conclui-se que qualquer regra deve ser interpretada conforme a Constituição e em caso de colisão prevalece sempre o mandamento da Carta Maior. 
Outro caso que pode ocorrer é a colisão entre uma regra constitucional e um princípio, prevalece a regra, conforme exemplifica Edgar Kohn:

Assim por exemplo, pode colidir com a regra, que proíbe a tortura, com o princípio da supremacia do direito público, num caso onde um suspeito saiba onde é escondida uma bomba. Nestes casos não se precisa ponderar o caso concreto, prevalece a regra. Não é admissível a tortura, não importa o motivo.[51]

Sendo assim, ao avaliar o caso em concreto, em uma colisão entre regras e princípios, o interprete deverá valer-se dos critérios hierárquicos entre as normas conflitantes, até chegar na melhor solução, buscando sempre dar prioridade a regra ou ao princípio que for constitucional.

\subsection{COLISÃO ENTRE PRINCÍPIOS}

Oportuno rever o conceito de princípio, o qual conforme ensina Celso Bandeira de Mello constituem o alicerce de um ordenamento jurídico, veja-se:

[...] mandamento nuclear de um sistema, verdadeiro alicerce dele, disposição fundamental que se irradia sobre diferentes normas compondo Ihes o espírito e servindo de critério para sua exata compreensão e inteligência exatamente por definira lógica e a racionalidade do sistema normativo, no que Ihe confere a tônica e lhe dá sentido harmônico.[52]

Ademais, os princípios, e principalmente os princípios que possuem direitos fundamentais, são de extrema importância em uma ordem jurídica, assim Bonavides ensina que "violar um princípio é muito mais grave que transgredir uma norma qualquer. A desatenção ao princípio implica ofensa não apenas a um específico mandamento obrigatório, mas a todo o sistema de comandos".[53]

Dada a importância dos direitos fundamentais em sua forma principiológica, é possível e provável que, por vezes ocorra uma colisão entre dois ou mais direitos dessa índole 
e tendo em vista que não existe hierarquia entre os princípios constitucionais, em especial entre os direitos fundamentais, pois a priori os princípios possuem o mesmo valor, quando houver uma colisão não existe a possibilidade de utilizar os critérios acima mencionados (cronológico, hierárquico ou especialidade).

Conforme ensina Jane Reis Gonçalves Pereira ao ressaltar sobre a impossibilidade de aplicação dos critérios tradicionais já estudados, quando se trata de colisão entre direitos fundamentais:

Desses aspectos inerentes ás colisões de direitos fundamentais deflui uma discussão sempre lembrada em doutrina: os conflitos que os envolvem não podem, normalmente, ser resolvidos recorrendo aos critérios clássicos de resolução de antinomias. O critério hierárquico lex superior derogat inferior - não vale, à medida que se trata de normas que estão no mesmo plano hierárquico. Também não é operativo o critério temporal - lex posterior derogat priori - pois que se trata de direitos positivados ao mesmo tempo. Por fim, sendo os conflitos de direitos fundamentais do tipo parcial-parcial e em concreto, não há, de um modo geral, resolução de especialidade entre eles, razão por que é ineficaz o critério lex specialis derogat generali. Não sendo apropriados tais critérios, impõe-se a utilização de outras técnicas hermenêuticas destinadas a determinar o direito aplicável nos casos de conflito.[54]

Entretanto, quando, em um caso concreto, houver esse conflito, o problema não poderá ficar sem solução, razão pela qual utiliza-se outros métodos de solução de conflitos, os quais são representados por três princípios, a saber: da unidade da constituição, da concordância prática e da proporcionalidade, que serão aprofundadas a seguir.

\section{COLISÃO ENTRE OS DIREITOS FUNDAMENTAIS}

Assim, como toda e qualquer norma, um direito fundamental poderá, em alguns casos, entrar em conflito com outro direito fundamental, cita-se como exemplo o direito à 
liberdade de imprensa em conflito com o respeito à vida privada, neste caso qual deverá prevalecer?

Desta forma convém mencionar o escólio de José Carlos Vieira de Andrade acerca da colisão entre preceitos fundamentais:

Haverá colisão ou conflito sempre que se deva entender que a Constituição protege simultaneamente dois valores ou bens em contradição concreta. A esfera de proteção de um certo direito é constitucionalmente protegida em termos de intersectar a esfera de outro direito ou de colidir com uma norma ou princípio constitucional. O problema agora é outro: é o de saber como vai resolver-se esta contradição no caso concreto, como é que se vai dar solução ao conflito entre bens, quanto ambos (todos) se apresentam efectivamente protegidos como fundamentais [...]. Terá, pois, de respeitar-se a proteção constitucional dos diferentes direitos ou valores, procurando a solução no quadro da unidade da Constituição, isto é, tentando harmonizar da melhor maneira os preceitos divergentes.[55]

Os direitos fundamentais são direitos heterogêneos, formados por regras e princípios, a colisão entre esses direitos pode se dar através de duas formas, tal como ensina Canotilho:

(1) o exercício de um direito fundamental colide com o exercício de outro direito fundamental (colisão entre os princípios direitos fundamentais); (2) o exercício de um direito fundamental colide com a necessidade de preservação de um bem coletivo ou do Estado protegido constitucionalmente (colisão entre direitos fundamentais e outros valores constitucionais).[56]

A primeira hipótese, quando a colisão se dá entre direitos fundamentais, a exemplo a liberdade artística, de comunicação ou informação (art. 5ำ, IX e XIV, CF) entrando em colisão com a intimidade privada ou a imagem das pessoas (art. 5º, X, CF)[57], por 
sua vez, a segunda hipótese ocorre quando há a colisão entre direitos fundamentais e outros valores constitucionais, quando, por exemplo, interesses individuais contrapõem-se a interesses da comunidade, todos reconhecidos pela constituição[58], a colisão destes princípios poderá se resolver através da aplicação de três princípios: o da unidade da constituição, o da concordância prática e o da ponderação[59].

\subsection{PRINCÍPIO DA UNIDADE DA CONSTITUIÇÃO}

Por este princípio entende-se que não há hierarquia entre as normas constitucionais, sendo que elas devem ser entendidas como um conjunto único e harmonioso, nesse sentido ensina o Ministro Luís Roberto Barroso que:

A ideia de unidade da ordem jurídica se irradia a partir da Constituição e sobre ela também projeta. Aliás, o princípio da unidade da Constituição assume magnitude precisamente pelas dificuldades geradas pela peculiaríssima natureza do documento inaugural da ordem jurídica. É a Carta fundamental do Estado, sobretudo quando promulgada em via democrática, e o produto dialético do confronto de crenças, interesses e aspirações distintos, quando não colidem. Embora expresse um consenso fundamental quanto a determinados princípios e normas, o fato é que isso não apaga "o pluralismo e antagonismo de ideias subjacentes ao pacto fundador. [...] A Constituição não é um conjunto de normas justapostas, mas um sistema normativo fundado em determinadas ideias que configuram um núcleo irredutível, condicionante da inteligência de qualquer de suas partes.[60]

Logo, este princípio é o primeiro a ser observado em uma colisão entre direitos fundamentais, visto que estes direitos são concorrentes, devendo ser exercidos simultaneamente, sem um se sobrepor ao outro, apenas quando isto não for possível acontecer - um direito ser exercido junto a outro - utilizar-se-á os próximos princípios elencados abaixo. 


\subsection{PRINCÍPIO DA CONCORDÂNCIA PRÁTICA}

O segundo princípio a ser analisado é o da concordância prática, também denominado de princípio da harmonização, foi construído na jurisprudência americana. Segundo Farias neste princípio "[...] os direitos fundamentais e valores constitucionais deverão ser harmonizados, no caso sub examine, por meio de juízo de ponderação que vise preservar e concretizar ao máximo os direitos e bens constitucionalmente protegidos"[61].

Conforme ensina J. J. Gomes Canotilho acerca do princípio da harmonização:

[... ] reduzido ao seu núcleo essencial, o princípio da concordância prática impõe a coordenação e combinação dos bens jurídicos em conflito de forma a evitar o sacrifício (total) de uns em relação aos outros [...] O campo de eleição do princípio da concordância prática tem sido até agora 0 dos direitos fundamentais (colisão entre direitos fundamentais ou entre direitos fundamentais e bens jurídicos constitucionalmente protegidos). Subjacente a este princípio está a ideia do igual valor dos bens constitucionais (e não uma diferença de hierarquia) que impede, como solução, o sacrifício de uns em relação aos outros, e impõe o estabelecimento de limites e condicionamentos recíprocos de forma a conseguir uma harmonização ou concordância prática entre estes bens.[62]

Portanto, para este, o interprete deve confrontar os bens conflitantes em face a constituição, estabelecendo qual valor deve prevalecer, evitando sempre o sacrifício total de um valor sobre o outro.[63]

\subsection{O PRINCÍPIO DA PROPORCIONALIDADE E A TÉCNICA DA PONDERAÇÃO}

Conforme mencionado não há hierarquia entre os princípios, pois não há incompatibilidade entre os princípios, mas sim há concorrência entre eles, por isso 
não é possível escolher qual deve prevalecer, ou mesmo excluir um princípio frente a outro, visto que os princípios devem ser levados em consideração como um conjunto complementável e harmonioso.

Portanto, quando houver um conflito entre os princípios resolver-se-á o imbróglio "levando-se em conta o peso ou a importância relativa de cada princípio, a fim de se escolher qual deles no caso concreto prevalecerá ou sofrerá menos contrição do que o outro"[64], para tanto utilizar-se-á a técnica da ponderação.

Ronald Dworkim ao escrever o livro Talking Rights Seriously, em 1977 foi um dos primeiros a desenvolver está técnica, entendendo que "nos casos difíceis, os juízes devem decidir conforme os princípios"[65]. Para o estudioso, enquanto as regras possuem consequências precisas e havendo colisão de regras uma delas deve sucumbir a outra, através dos critérios já estudados, nos princípios há uma dimensão de peso entre uns e outros, preponderando aquele que tiver o peso maior.[66]

Outro grande autor que escreveu sobre a ponderação - o qual denominava de sopesamento - foi o Alemão Robert Alexy em sua obra: Teoria dos direitos fundamentais, de 1986, entendendo que os princípios são mandamentos de otimização, aplicados gradualmente conforme a possibilidade jurídica e social de sua efetiva concretização, devendo ser aplicados também com a ponderação do interprete frente à realidade fática e jurídica do caso[67].

Para Alexy, na colisão de princípios não se aplica a lógica da invalidade, tal como nas regras, mas resolve-se pela aplicação da lei de colisão, a qual se determina que o princípio ganhará maior peso na relação de precedência condicionada e que deverá regular o fato, a partir disso, extrai-se uma operação lógico-hermenêutica, uma regra que vai dirimir o conflito[68].

Assim, a técnica da ponderação trata-se de um processo no qual em um caso específico, o intérprete, analisará e verificará, segundo critérios subjetivos e objetivos, qual valor que o ordenamento deseja preservar na situação conflituosa, buscando 
conciliar os princípios divergentes, buscando a composição entre ambos. Assim, ensina o Ministro Luís Roberto Barroso o que seria o processo da ponderação:

A ponderação consiste, portanto, em uma técnica de decisão jurídica aplicável a casos difíceis, em relação aos quais a subsunção se mostrou insuficiente, sobretudo quando uma situação concreta dá ensejo à aplicação de normas de mesma hierarquia que indicam soluções diferenciadas. A estrutura interna do raciocínio ponderativo ainda não é bem conhecida, embora esteja sempre associada às noções difusas de balanceamento e sopesamento de interesses, bens, valores ou normas. A importância que o tema ganhou no cotidiano da atividade jurisdicional, entretanto, tem levado a doutrina a estudá-lo mais cuidadosamente.[69]

Também ensina Thomas Bustamante a técnica da ponderação desenvolvida primordialmente por Robert Alexy, se dará a partir da aplicação dos seguintes preceitos:

[...] A hipótese 2 (colisão de princípios constitucionais) é solucionada necessariamente pelo método da ponderação. O resultado de uma ponderação é determinado por um conjunto de fatores que inclui (i) o grau de proteção de um princípio e o grau de restrição em outro; (ii) o peso abstrato dos princípios colidentes; (iii) o grau de confiabilidade (à luz dos parâmetros da ciência e do conhecimento em um dado momento) das premissas empíricas utilizadas para concluir que um determinado princípio é protegido ou restringido; (iv) o número de princípios que justificam uma ou outra decisão; e (v), na hipótese iv, a forma como interagem os princípios que se inclinam para uma determinada decisão (se seus pesos meramente se somam ou se eles se reforçam mutuamente).[70]

O Ministro Luís Roberto Barroso, ainda explicando como se deve aplicar a técnica da ponderação, dividindo-a em três etapas distintas que o interprete deverá se atentar: 
Na primeira etapa, cabe ao intérprete detectar no sistema as normas relevantes para a solução do caso, identificando eventuais conflitos entre elas. Como se viu, a existência dessa espécie de conflito - insuperável pela subsunção - é o ambiente próprio de trabalho da ponderação [...] $\mathrm{Na}$ segunda etapa, cabe examinar os fatos, as circunstâncias concretas do caso e sua interação com os elementos normativos. Como se sabe, os fatos e as consequências práticas da incidência da norma têm assumido importância especial na moderna interpretação constitucional. [...] É na terceira etapa que a ponderação irá singularizarse, em oposição à subsunção [...] Em seguida, é preciso ainda decidir quão intensamente esse grupo de normas - e a solução por ele indicada - deve prevalecer em detrimento dos demais, isto é: sendo possível graduar a intensidade da solução escolhida, cabe ainda decidir qual deve ser o grau apropriado em que a solução deve ser aplicada. Todo esse processo intelectual tem como fio condutor o princípio instrumental da proporcionalidade ou razoabilidade.[71]

Portanto, quando se está diante de conflitos entre princípios com carga valorativa de direito fundamental, a ponderação deve ser utilizada de acordo com o princípio da proporcionalidade, isto quer dizer que, os princípios de direitos fundamentais não são absolutos, por isso podem ser restringidos, desde que está limitação sirva para proteger outro valor igualmente importante.

Robert Alexy, que foi o principal expoente a tratar sobre a técnica da ponderação, como já mencionado, vaticina a respeito do princípio da proporcionalidade e sua aplicação:

O postulado da proporcionalidade em sentido estrito pode ser formulado como uma lei de ponderação, cuja fórmula mais simples voltada para os direitos fundamentais diz: o quanto mais intensa se revelar a intervenção em um dado direito fundamental, maiores hão de revelar os fundamentos justificadores desta intervenção.[72] 
Ademais, Alexy não indica os critérios para a aplicação do sopesamento, no entanto, estabelece em sua celebre obra, que a ponderação deve ser feita sob a máxima da proporcionalidade:

Princípios são mandamentos de otimização em face das possibilidades jurídicas e fáticas. A máxima da proporcionalidade em sentido estrito, ou seja, exigência do sopesamento, decorre da relativização em face das possibilidades jurídicas. Quando uma norma de direito fundamental com caráter de princípio colide com um princípio antagônico, a possibilidade jurídica para a realização dessa norma depende do princípio antagônico. Para se chegar a uma decisão é necessário um sopesamento nos termos da lei de colisão. [...] Já as máximas da necessidade e da adequação decorrem da natureza dos princípios como mandamentos de otimização em face das possibilidades fáticas.[73]

A proporcionalidade teve origem no direito administrativo prussiano, este princípio, principalmente quando vinculado a defesa dos direitos fundamentais contra intervenções desproporcionais, opera como um limite e ocorrem sob três fundamentos: adequação, necessidade ou exigibilidade e proporcionalidade em sentido estrito, estes postulados que formam a proporcionalidade podem ser conceituados da seguinte forma:

Pelo subprincípio da adequação pode-se entender que devem ser adotadas medidas apropriadas ao alcance da finalidade prevista no mandamento que pretende cumprir. [...] O subprincípio da necessidade exige que o Poder Judiciário apure se a medida ou a decisão tomada, dentre as aptas à consecução do fim pretendido, é a que produz menor prejuízo aos cidadãos envolvidos ou à coletividade. [...] Pelo subprincípio da ponderação ou da proporcionalidade em sentido estrito se pretende alcançar parâmetros para a resolução dos conflitos entre princípios constitucionais, nos casos em que o Poder Judiciário é chamado a decidir pela prevalência de um princípio em detrimento de outro ou outros, reconhecidamente válidos pelo ordenamento constitucional.[74] 
Sendo assim, em uma colisão entre princípios, é necessário realizar uma ponderação entre eles, de forma proporcional, buscando harmonizá-los sempre que possível, podendo até deixar de aplicar partes de um princípio, mas sempre respeitando o seu núcleo fundamental.

Logo, os três princípios supramencionados, devem ser analisados conjuntamente diante do caso concreto em que houver uma colisão entre direitos fundamentais, após está analise o interprete deverá verificar a natureza da norma - se trata de regra ou de princípio - daí então, aplicar as técnicas de solução de conflitos acima estudadas.

Se o conflito for entre princípios o interprete aplicará a técnica da ponderação, levando em conta sempre a proporcionalidade; já se o conflito for entre regras utiliza-se os critérios hierárquico, cronológico e especialidade; por fim, sendo o conflito entre regras e princípios o interprete deverá avaliar o caso e aplicar a norma constitucional de maior hierarquia, buscando priorizar a aplicação dos mandamentos previstos na Constituição Federal.

\subsection{POSIÇÃO DOS TRIBUNAL BRASILEIROS SOBRE A COLISÃO ENTRE OS DIREITOS FUNDAMENTAIS}

A colisão entre direitos fundamentais pode e deve ser resolvida através da aplicação de alguns princípios e/ou critérios, a depender da natureza jurídica das normas conflitantes. O Supremo Tribunal Federal (STF), trilha um caminho de acordo com as orientações proferidas pelas cortes constitucionais alemã, italiana, francesa, espanhola, portuguesa e americana, entendendo que é impossível o escalonamento dos direitos fundamentais, pois todos possuem a mesma proteção constitucional[75], diante disso quando houver uma colisão de direitos fundamentais com viés principiológico, tem-se aplicado em seus julgados a ponderação de interesses através da aplicação do princípio da proporcionalidade.

Pode-se citar como exemplo de aplicação do princípio da ponderação/ proporcionalidade como pressuposto para resolução de conflitos de direitos fundamentais, nos seguintes julgados: HC 89544/RN; HC 79512/RJ; HC 82424/RS; 
ARE 801676 AgR/PE; HC 71373/RS; HC 94477/PR; ADI 4650/DF; ADPF 347 MC/DF; RE 592581/RS/ ADI 4815/ DF; RE 658312/SC; RE 636941/SC; HC 115613/SP, dentre outros.

Ressalta-se que o pretório excelso, além de aplicar a técnica da ponderação e o princípio da proporcionalidade na colisão de direitos, deve ter como alicerce, tal como induz a Constituição Federal, o princípio da dignidade da pessoa humana, portanto não basta apenas resolver o conflito, a solução deve ser digna, e assegurar o núcleo essencial dos princípios conflitantes, assumindo aquele princípio, uma grande importância no choque entre direitos fundamentais, sobre o tema destaca-se o escólio de Gilmar Ferreira Mendes:

Fica evidente aqui que, também no Direito brasileiro, o princípio da dignidade humana assume relevo ímpar na decisão do processo de ponderação entre as posições em conflito. É certo, outrossim, que o Supremo Tribunal Federal está a se utilizar, conscientemente, do princípio da proporcionalidade como "lei de ponderação", rejeitando a intervenção que impõe ao atingido um ônus intolerável e desproporcional.[76]

O jurista Ingo Wolfgang Sarlet retrata muito bem essa posição do Supremo, ao aplicar a teoria da ponderação, embasando-a nos princípios da proporcionalidade e da dignidade da pessoa humana, veja-se:

[...] doutrina e jurisprudência, notadamente o STF, embora adotem a tese da posição preferencial da liberdade de expressão, admitem não se tratar de direito absolutamente infenso a limites e restrições, desde que eventual restrição tenha caráter excepcional, seja promovida por lei e/ou decisão judicial (visto que vedada toda e qualquer censura administrativa) e tenha por fundamento a salvaguarda da dignidade da pessoa humana (que aqui opera simultaneamente como limite e limite aos limites de direitos fundamentais) e de direitos e bens jurídicosconstitucionais individuais e coletivos fundamentais, observados os 
critérios da proporcionalidade e da preservação do núcleo essencial dos direitos em conflito.[77]

Ademais, Virgílio Afonso da Silva explica que o Supremo, aplica o princípio da proporcionalidade, mas o faz de uma forma menos criteriosa, do que realmente deveria ser:

A invocação da proporcionalidade é, não raramente, um mero recurso a um topos, com caráter meramente retórico e não sistemático. Em inúmeras decisões, sempre que se queira afastar alguma conduta considerada abusiva, recorre-se à fórmula 'à luz do princípio da proporcionalidade ou da razoabilidade, 0 ato deve ser considerado inconstitucional'. (...) Não é feita nenhuma referência a algum processo racional e estruturado de controle da proporcionalidade do ato questionado, nem mesmo um real cotejo entre os fins almejados e os meios utilizados.[78]

Certo é, que os tribunais brasileiros, principalmente o Supremo Tribunal Federal, utiliza-se os critérios aqui estudados, em especial o dá ponderação e da proporcionalidade, no conflito entre normas de direitos fundamentais, sempre analisando a natureza jurídica das normas conflitantes no caso. Assim, como é o foco do trabalho, necessário se faz analisar alguns casos em que houve a solução do conflito de direitos fundamentais através da técnica da ponderação e do princípio da proporcionalidade, conforme se exporá abaixo.

\section{ANÁLISE DE CASOS PRÁTICOS}

\subsection{LIBERDADE DE IMPRENSA E O DIREITO DE INFORMAR VERSUS DIGNIDADE DA PESSOA HUMANA}

O primeiro caso prático a ser analisado no presente estudo, é um tema que envolve duas grandes espécies de direitos fundamentais que é o direito à liberdade de informação conflitando com o direito à dignidade da pessoa humana. 
Sempre é veiculado na mídia informações a respeito de determinadas pessoas ou acontecimentos e esse direito - a informação - é assegurado pela própria Constituição Federal (art. 5, inciso IV CF), por isso José Afonso da Silva conceitua-o como sendo:

[...] o conhecimento de fatos, de acontecimentos, de situações de interesse geral e particular. [...] a liberdade de informação compreende a procura, o acesso, o recebimento e a difusão de informações ou ideias, por qualquer meio, e sem dependência de censura, respondendo cada qual pelos abusos que cometer. $\mathrm{O}$ acesso de todos à informação é um direito individual consignado na Constituição, que também resguarda o sigilo da fonte, quando necessário ao sigilo profissional [...].[79]

Contudo, o conflito surge quando essas notícias trazem informações vexatórias, inverídicas ou que expõe a pessoa ao ridículo, violando assim o direito ao respeito à dignidade da pessoa humana e sua imagem das pessoas, direito esse, que também é assegurado pela Carta Magna (art. 1ํ, III, CF).

Assim, Ingo Wofgang Sarlet conceitua o princípio da dignidade da pessoa humana como:

A dignidade da pessoa humana corresponde à qualidade intrínseca e distintiva de cada ser humano que o faz merecedor do mesmo respeito e consideração por parte do Estado e da comunidade, implicando, neste sentido, um complexo de direitos e deveres fundamentais que assegurem a pessoa tanto contra todo e qualquer ato de cunho degradante e desumano, como venham a the garantir as condições existenciais mínimas para uma vida saudável, além de propiciar e promover a sua participação ativa e co-responsável nos destinos da própria existência e da vida em comunhão com os demais seres humanos.[80] 
Este princípio foi alçado na Constituição Federal de 1988 como um fundamento do estado democrático de direito, sendo encontrado logo no início do texto em seu artigo $1^{\circ}$, inciso III[81] e ao "[...] reconhecer categoricamente que é o Estado que existe em função da pessoa humana, e não o contrário, já que o ser humano constitui finalidade precípua, e não meio da atividade estatal"[82].

O presente estudo analisará um julgado, podendo dizer que é um dos principais, quando o assunto é a aplicação da proporcionalidade e ponderação no conflito de direitos fundamentais e também teve significativas e importantes considerações acerca do princípio da dignidade humana, trata-se do Habeas Corpus n. 82.442/RS, famoso caso Siegefried Ellwanger[83].

O caso foi o seguinte, Ellwanger era um escritor, que foi condenado pelo Tribunal de Justiça do Rio Grande do Sul (TJRS) pelo crime de racismo, pois possuía em seus livros uma visão antissemita e alegava que os judeus não eram uma raça[84]. A partir da condenação pelo Egrégio Tribunal, irresignado, o autor impetrou um habeas corpus (HC) no Supremo Tribunal Federal, sob o n.. 82.424-2, sustentando a tese da prescritibilidade do crime praticado[85]. Após, longas sessões e discussões na corte, o HC levou 09 (nove) meses para ser julgado e "por maioria de sete a três, o Plenário negou o recurso, vencidos os ministros Moreira Alves, Marco Aurélio e Carlos Ayres Britto. Os dois primeiros consideraram o crime prescrito. Ayres Britto concedia o recurso de ofício para absolver o livreiro por falta de provas"[86], mantendo assim a condenação imposta pelo TJRS.

Ressalta-se que o Ministro Gilmar Mendes destacou, no julgado em análise, incluindo um tópico para falar apenas sobre o princípio da proporcionalidade, explicando-a, nos seguintes termos:

O princípio da proporcionalidade, também denominado princípio do devido processo legal em sentido substantivo, ou ainda, princípio da proibição do excesso, constitui uma exigência positiva e material relacionada ao conteúdo de atos restritivos de direitos fundamentais, de modo a estabelecer um 'limite do limite' ou uma 'proibição de excesso' 
na restrição de tais direitos [...] Nesse sentido, o princípio ou máxima da proporcionalidade determina o limite último da possibilidade de restrição legítima de determinado direito fundamental. A par dessa vinculação aos direitos fundamentais, o princípio da proporcionalidade alcança as denominadas colisões de bens, valores ou princípios constitucionais. Nesse contexto, as exigências do princípio da proporcionalidade representam um método geral para a solução de conflitos entre princípios, isto é, um conflito entre normas que, ao contrário do conflito entre regras, é resolvido não pela revogação ou redução teleológica de uma das normas conflitantes nem pela explicitação de distinto campo de aplicação entre as normas, mas antes tão-somente pela ponderação do peso relativo de cada uma das normas em tese aplicáveis e aptas a fundamentar decisões em sentidos opostos. Nessa última hipótese, aplica-se o princípio da proporcionalidade para estabelecer ponderações entre distintos bens constitucionais.[87]

O Ministro Carlos Velloso, embora não tenha usado o termo proporcionalidade, entendeu que a "a liberdade de expressão não pode sobrepor-se à dignidade da pessoa humana, fundamento da república e do Estado Democrático de Direito que adotamos- CF, art. $1^{\circ}$, III- ainda mais quando essa liberdade de expressão apresentase distorcida e desvirtuada"[88]. Nota-se uma clara aplicação, ainda que de modo implícito, do princípio ora analisado.

Caminhando pelo mesmo sentido o Ministro Nelson Jobim também ponderou os direitos conflitantes, entendendo a dignidade se sobrepõe acima do direito à liberdade de expressão:

Em situações como a presente, acaso caracterizado o conflito, devem preponderar os direitos de toda a parcela da sociedade atingida com a publicação das obras sob a responsabilidade do paciente, sob pena de colocar-se em jogo a dignidade, a cidadania, o tratamento igualitário, e até mesmo a própria vida dos que se acham sob a mira desse eventual risco.[89] 
Também o Ministro Marco Aurélio ao analisar o caso, entendeu com fulcro na teoria alexyana que a colisão de direitos fundamentais "[...] necessita, assim, de uma atitude de ponderação dos valores em jogo, decidindo-se, com base no caso concreto e nas circunstancias da hipótese, qual o direito que deverá ter primazia”.[90] Já o ministro Celso de Mello, ao denegar o HC entendeu que a colisão de direitos fundamentais se dá por:

[...] critérios que the permitam ponderar e avaliar, 'hic et nunc', em função de determinado contexto e sob uma perspectiva axiológica concreta, qual deva ser o direito a preponderar no caso, considerada a situação de conflito ocorrente, desde que, no entanto, a utilização do método da ponderação de bens e interesses não importe em esvaziamento do conteúdo essencial dos direitos fundamentais.[91]

Assim, observa-se que tanto os votos vencidos quanto os vencedores utilizaram-se da mesma técnica da ponderação para solucionar o conflito[92]. Outrossim, muito embora, alguns ministros não utilizassem o termo adequado - proporcionalidade entenderam, em sua grande maioria, que a dignidade da pessoa humana possui um peso maior, portanto, a questão trazida ao Supremo no conflito entre a liberdade de expressão e a dignidade humana, ambos alçados pela Constituição Federal de 1988 como direitos fundamentais, inerentes a qualquer pessoa, entendeu os ministros da suprema corte que a dignidade deve prevalecer frente a liberdade de expressão, pois de acordo com o princípio da proporcionalidade, aquele é mais condizente com o que almeja a Carta Magna[93].

\subsection{INTEGRIDADE FÍSICA VERSUS DIREITO AO CONHECIMENTO DA PATERNIDADE NO EXAME DE SANGUE FORÇADO EM INVESTIGAÇÃO DE PATERNIDADE}

Outro caso emblemático que envolve a colisão entre direitos fundamentais, é a questão da integridade física conflitando com o direito ao conhecimento da paternidade. O julgado, ora em análise, chegou ao Supremo Tribunal Federal e este, 
ao dirimir o conflito, utilizou-se da técnica da ponderação baseado na teoria de Robert Alexy, conforme se exporá abaixo.

O caso, sub judice, trata-se do Habeas Corpus $\mathrm{n} .{ }^{0}$ 71.373-4/RS, e consiste em uma ação de reconhecimento de paternidade, onde o juiz da Vara de Família e Sucessões de Porto Alegre/RS determinou a realização do exame de DNA do suposto pai, este negou-se a realizar, razão pela qual o juízo determinou a execução forçada da decisão, a qual foi mantida pelo Tribunal de Justiça do Rio Grande do Sul (TJRS)[94].

Inconformado com a decisão que o obrigava a realizar o exame para confirmar ou não a paternidade, o suposto pai impetrou um habeas corpus perante o STF, o qual chegou às mãos do ministro relator Francisco Rezek, que sustentou:

O que temos agora em mesa é a questão de saber qual o direito deve preponderar nas demandas de verificação de paternidade: o da criança a seu real (e não apenas presumida) identidade, ou o do indigitado pai a sua intangibilidade física.[95]

O HC, por uma maioria de votos o STF concedeu o pedido e a tese que prevaleceu foi a que direito a integridade física do pai deveria sobrepor-se ao direito ao reconhecimento da paternidade.[96] Apesar da decisão, muitos entenderam que a mesma não foi correta, conforme ensina José Critóvam:

A intangibilidade do corpo humano é passível de restrições, como, para exemplificar, a determinação estatal de vacinação forçada para controlar doença de proporções epidêmicas [...] O sacrifício imposto à integridade corporal do suposto pai é, em última análise, risível frente ao direito da criança em conhecer sua origem real, direito que decorre da própria extensão do princípio constitucional da dignidade da pessoa humana, inscrito no artigo 1ํ, inciso III da Constituição da República.[97]

Mas, mesmo sendo alguns ministros e até alguns estudiosos contra essa decisão do STF, por entender que o direito da criança deveria prevalecer, a ementa ficou escrita assim: 
INVESTIGAÇÃO DE PATERNIDADE - EXAME DNA - CONDUÇÃO DO RÉU "DEBAIXO DE VARA". Discrepa, a mais não poder, de garantias constitucionais implícitas e explícitas - preservação da dignidade humana, da intimidade, da intangibilidade do corpo humano, do império da lei e da inexecução específica e direta de obrigação de fazer provimento judicial que, em ação civil de investigação de paternidade, implique determinação no sentido de o réu ser conduzido ao laboratório, "debaixo de vara", para coleta do material indispensável à feitura do exame DNA. A recusa resolve-se no plano jurídico-instrumental, consideradas a dogmática, a doutrina e a jurisprudência, no que voltadas ao deslinde das questões ligadas à prova dos fatos.[98]

Contudo, verifica-se que o que foi ponderado pela suprema corte, não foi o direito ao conhecimento da paternidade, mas a obtenção de uma prova judicial de maneira forçada (através do exame) versus a integridade física do suposto pai, visto que poderia obter-se esta prova de outras formas.

\subsection{DIGNIDADE DA PESSOA HUMANA VERSUS DIREITO À VIDA NO CASO DOS FETOS ANENCÉFALOS}

Por fim, o último caso a ser analisado no presente trabalho, trata-se da Arguição de Descumprimento de Preceito Fundamental (ADPF) n.ํ5/DF, na qual fora ajuizada a ação para viabilizar a realização de interrupção de gravidez em razão de anencefalia fetal, ressalta-se que está condição consiste em:

A anencefalia é uma má-formação do sistema neurológico de grande envergadura, na maioria dos casos é mesmo incompatível com a vida. Estatísticas médicas apontam para o fato de que apenas $25 \%$ dos anencéfalos apresentam sinais vitais na 1a semana após o parto. A incidência é de cerca de 2 a cada 1.000 nascidos vivos. O seu diagnóstico pode ser estabelecido mediante ultrassonografia por volta da 15a. semana de gestação e pelo exame da alfa-fetoproteína no soro 
e no líquido amniótico, que está aumentada em 100\% dos casos em torno da 11a à 16a semana de gestação.[99]

A ADPF $n . .54$, partiu do pressuposto que a gestante de um feto anencefálico estaria correndo risco de vida, que não há viabilidade de vida para o feto e que levar a gestação adiante causaria inúmeros transtornos psicológicos e físicos à gestante[100], por estes motivos a Corte julgou procedente a ação e liberou o aborto dos anencéfalos, tendo em vista a inviabilidade, da grande maioria, destes fetos, que ao nascerem morrem logo em seguida, o Supremo votou favorável, em colocar a dignidade da pessoa da gestante frente ao direito a vida do feto.

Nesse diapasão convém transcrever os ensinamentos de Lília Nunes dos Santos a respeito do princípio da dignidade da pessoa humana:

Nesta perspectiva, o constituinte originário elegeu o princípio da dignidade da pessoa humana como fundamento e norte de todo o ordenamento jurídico brasileiro, na medida em que estabelece a tutela e a proteção de todo o ser humano, ou seja, de todo indivíduo pertencente à espécie humana, independentemente de qualquer distinção. $O$ respeito à dignidade do homem decorre, simplesmente, deste atributo que the é inerente por natureza e que possui valor absoluto, o qual antecede todas as formas de reconhecimento pelo Estado.[101]

Entretanto, esta decisão não agradou muitas pessoas, incluindo grandes nomes da doutrina, como Maria Helena Diniz, a qual sustentou que está prática - aborto de anencéfalos - seria:

[...] uma barbárie de um sintoma de desumanização, aliás, uma escala para a instalação de câmaras de extermínio de recém-nascidos defeituosos, para a eutanásia de deficientes físicos e mentais e para a eliminação de velhos não produtivos. Que tipo de motivos "caridosos" os filhos não poderiam alegar para justificar a "boa ação" de eliminar seus 
pais idosos e doentes? Urge amparar, proteger e respeitar a vida intra ou extrauterina.[102]

Sem adentrar ao mérito do debate, se a decisão foi correta ou não, o que importa mencionar, o voto de algum dos ministros no decisum, conforme salientou o relator Marco Aurélio:

Não se coaduna com o princípio da proporcionalidade proteger apenas um dos seres da relação, privilegiar aquele que, no caso da anencefalia, não tem sequer expectativa de vida extrauterina, aniquilando, em contrapartida, os direitos da mulher, impingindo-lhe sacrifício desarrazoado.[103]

O Ministro César Peluso em seu voto abriu um tópico apenas para dizer sobre "Ponderação de valores entre a vida do feto anencéfalo e a dignidade, a integridade, a liberdade e a saúde da gestante. Direitos reprodutivos da mulher"[104], aplicando inclusive a formula desenvolvida por Alexy - acima estudada - entendendo que a gestante deve ter autonomia para escolher, caso comprovada a anencefalia, se mantem ou interrompe a gestação[105].

Luiz Fux também, ao decidir ponderou entre os bens conflitantes, aplicando o princípio da proporcionalidade, veja-se:

A resolução do presente conflito entre o direito fundamental à vida digna de um lado e o direito social à saúde e à autonomia da vontade requer $\mathrm{o}$ exame de princípios a serem relevados no caso posto a exame. Ao julgador a tarefa de fazer a ponderação de bens jurídicos tutelados pelo sistema, todos de inegável relevo para a vida de cada pessoa e da sociedade. Exercitam-se, aqui, o que a doutrina denomina de ponderação de princípios na teoria da proporcionalidade.[106]

Finalmente, a corte decidiu que o direito à vida digna da gestante, está poderá escolher, caso comprovada a anencefalia do feto, se interrompe ou não a gravidez, e 
caso opte em interromper não responderá por crime, colocando está conduta como atípica frente ao direito penal.

\section{CONCLUSÃO}

Tendo em vista tudo o que foi exposto e analisado no presente estudo, se percebe que os direitos fundamentais possuem uma grande importância e quando há colisão entre eles é necessário fazer um juízo de ponderação, colocando os valores colidentes e sopesando qual deverá prevalecer sobre o outro, contudo, não pode excluir-se totalmente a aplicação de um direito sobre o outro, apenas deve-se dar um pouco mais de peso a um direito, deixando o outro em segundo plano. $O$ estudo tratou basicamente em buscar as possíveis soluções de conflitos entre os direitos fundamentais.

Assim, considerando que estes direitos podem possuir natureza dúplice, ora regra, ora princípio, num eventual conflito necessário se fazer, em um primeiro momento, um estudo a respeito da natureza jurídica dos preceitos colidentes. Se as normas conflitantes forem consideradas regras utiliza-se o critério hierárquico onde a norma superior derroga inferior; o cronológico, a norma posterior derroga anterior; e da especialidade, quando o conflito for entre uma norma geral e outra específica, prevalecerá está.

Já, quando o conflito for entre princípios e regras, o interprete deverá adotar o critério hierárquico, aplicando aquele que tiver maior força no ordenamento, a exemplo o conflito entre um princípio constitucional e uma regra infraconstitucional, prevalecerá aquele, já se a regra e o princípio possuírem a mesma hierarquia, deve prevalecer o princípio, por ser um preceito mais aberto.

Por sua vez, quando o conflito for entre princípios, utiliza-se para a solução do imbróglio os seguintes princípios, nesta ordem: da unidade da constituição, da concordância prática e o da proporcionalidade, este último, como visto, é o mais utilizado pelos Tribunais, em especial pelo Supremo Tribunal Federal, que o aplica 
aliado a técnica da ponderação, que consiste em uma forma de sopesar os princípios conflitantes, chegando a conclusão sobre qual deve prevalecer frente ao outro.

Além das formas de solução de conflito entre os direitos fundamentais, analisou-se casos práticos em que a técnica da ponderação e o princípio da proporcionalidade foram aplicados diante de fatos concretos julgados pelo Supremo, visto que este é a última instancia do Poder Judiciário brasileiro e é o guardião da Constituição Federal, razão pela qual deve interpretar a Carta Magna, calcado nos princípios nela expressos, em especial o da dignidade da pessoa humana, e ao encontrar um conflito entre os preceitos constitucionais, deve dar solução ao caso sub judice, ponderando os valores colidentes, de forma proporcional e buscando sempre a aplicação e interpretação da Lei Maior de forma demonstrar sua importância para um ordenamento jurídico.

\section{REFERÊNCIAS}

ACUNHA, Fernando José Gonçalves. Colisão de normas: distinção entre ponderação e juízo de adequação. Revista Senado. Brasília/DF Ano 51 Número 203 jul./set. 2014. Disponível em: <http://www2.senado.leg.br/bdsf/bitstream/handle/id/507411/001017676.pdf?seq uence $=1$ >. Acesso em: 18 dez. 2018.

AGRA, Walber de Moura. Curso de Direito Constitucional. 9. ed. Belo Horizonte: Fórum, 2018.

ALEXY, Robert. Teoría de los Derechos Fundamentales. Madrid: Centro de Estudios Constitucionales. 1993.

Robert. Teoria dos direitos fundamentais. Tradução de Virgílio Afonso da Silva, São Paulo: Malheiros, 2008.

AMARAL, Fernando. A distinção entre princípios e regras, a ordem Constitucional brasileira e a cidadania ecológica: uma proposta doutrinaria. Publica Direito. 
Disponível em <http://www.publicadireito.com.br/artigos/?cod=76a46a2fef5c9dd7>. Acesso em 17 nov. 2018.

ANDRADE, José Carlos Vieira de. Os Direitos Fundamentais na Constituição Portuguesa de 1976. Coimbra: Almedina, 1987.

BANDEIRA DE MELLO, Celso Antônio. Curso de direito administrativo. São Paulo: Malheiros, 1999.

BARROSO, Luís Roberto. Interpretação e Aplicação da Constituição. 6‥ ed. rev., atual. e ampl. São Paulo: Saraiva, 2004.

BRASIL. Superior Tribunal de Justiça. Recurso Especial n.o 1.529.043 - PR. Relator Herman Benjamin, Brasília, DF, 26 mai. 2015. Disponível em: < https://ww2.stj.jus.br/processo/revista/documento/mediado/?componente=MON\&seq uencial=48288459\&num_registro=201500976781\&data=20150619\&formato=PDF $>$. Acesso em: $22 \mathrm{dez}$.

BRASIL. Superior Tribunal de Justiça. STF nega Habeas Corpus a editor de livros condenado por racismo contra judeus, Brasília, DF, 17 set. 2003. Disponível em: < http://www.stf.jus.br/portal/cms/verNoticiaDetalhe.asp?idConteudo=61291>. Acesso em: 22 dez.

BRASIL. Superior Tribunal Federal. Arguição de descumprimento de preceito fundamental n. 54-DF. Relator Ministro Marco Aurélio, Brasília, DF, 12 abr. 2012. Disponível em:

http://portal.stf.jus.br/processos/downloadPeca.asp?id=136389880\&ext=.pdf>. Acesso em: 26 dez. 2018, p. 68.

BRASIL. Superior Tribunal Federal. Habeas Corpus n. 71373-4-RS. Relator Francisco Rezek, Brasília, DF, 10 nov. 1994. Disponível em: < http://redir.stf.jus.br/paginadorpub/paginador.jsp?docTP=AC\&doclD=73066>. Acesso em: 24 dez., p. 01-02. 
BRASIL. Superior Tribunal Federal. Habeas Corpus n.o 82.424-RS. Relator Moreira Alves, Brasília, DF, 17 set. 2003. Disponível em: <http://redir.stf.jus.br/paginadorpub/paginador.jsp?docTP=AC\&doclD=79052>. Acesso em: 23 dez. p. 134-135.

BOBBIO, Norberto. A era dos direitos. Tradução de Carlos Nelson Coutinho, Rio de Janeiro: Campus, 2004.

BONAVIDES, Paulo. Curso de direito constitucional. 7. ed. rev., atual. e ampl. São Paulo: Malheiros, 1997. Apud Pedro Lenza. Direito Constitucional Esquematizado. 22. ed., São Paulo: Saraiva, 2018.

BUSTAMANTE, Thomas. Princípios, regras e conflitos normativos: uma nota sobre a superabilidade das regras jurídicas e as decisões contra legem. Disponível em:

$<$ http://direitoestadosociedade.jur.pucrio.br/media/Artigo7\%20Thomas.pdf> Acesso em: 19 dez. 2018.

CANOTILHO, J. J. Gomes; MOREIRA, Vital. Fundamentos da Constituição. Coimbra: Coimbra, 1991, p. 135. Apud Edílson Pereira de Farias. Colisão de Direitos: A honra, a intimidade, a vida privada e a imagem versus a liberdade de expressão e informação. 2. ed. Porto Alegre: PC Editorial Ltda, 1996.

CRISTÓVAM, José Sérgio da Silva. A resolução das colisões entre princípios constitucionais. Revista Jus Navigandi, ISSN 1518-4862, Teresina, ano 8, n. 62, 1 fev. 2003. Disponível em: <https://jus.com.br/artigos/3682>. Acesso em: 19 dez. 2018. , José Sérgio da Silva. Colisão entre princípios constitucionais: uma abordagem a partir da teoria de Robert Alexy. Domínio Público. Disponível em: <http://www.dominiopublico.gov.br/download/teste/arqs/cp032730.pdf>.Acesso em: 19 dez. 2018.

DAMACENO, Gian Carlos. Há colisão de direitos fundamentais? Revista Jus.com, Brasília-DF, 10 out. 2014. Disponível em:<https:/jus.com.br/artigos/32635/hacolisao-de-direitos-fundamentais>. Acesso em: 19 dez. 2018. 
DINIZ, Maria Helena. Conflito de Normas. 5. ed. São Paulo: Saraiva, 2005. , Maria Helena. O Estado Atual do Biodireito. 9. ed. São Paulo: Saraiva, 2014.

DWORKIN, Ronald. Levando os direitos a sério. Tradução de Nelson Boeira. 1. ed. São Paulo: Martins Fontes, 2002.

GOMES CANOTILHO. J. J. Direito Constitucional e Teoria da Constituição. 4..$^{a}$ edição. Almedina. Coimbra. 2003.

HORACIO, Lincoln. Distinção entre Princípios e Regras e Critérios de Ponderação em Caso de Conflitos Principiológicos. Conteúdo Jurídico, Brasília-DF: 09 mar. 2016. Disponível em: <http://www.conteudojuridico.com.br/?artigos\&ver=2.55392\&seo=1>. Acesso em: 19 dez. 2018.

JÚNIOR OLIVEIRA, Juarez Monteiro de. O habeas corpus 82.424-2 e a construção dos conceitos de liberdade de expressão e dignidade da pessoa. In: XVIII Congresso Nacional do CONPEDI, São Paulo/SP: 04, 05, 06 e 07 nov. 2009. Disponível em: <http://www.publicadireito.com.br/conpedi/manaus/arquivos/anais/sao_paulo/2713.p df>. Acesso em: 22 dez. 2018. p. 04.

KÖHN, Edgar. Princípios e regras e sua identificação na visão de Robert Alexy. Boletim Jurídico, Uberaba/MG, a. 4, no 188. Disponível em: < https://www.boletimjuridico.com.br/doutrina/artigo/1440/principios-regrasidentificacao-visao-robert-alexy> Acesso em: 18 dez. 2018.

LENZA, Pedro. Direito Constitucional Esquematizado. 22. ed. São Paulo: Saraiva, 2018.

LOPES, Lorena Duarte Santos. A (in)adequada recepção da ponderação alexyana pelo direito brasileiro. Repositório digital da Biblioteca da Unisinos. São Leopoldo/RS. $\quad 12$ dez. $2014 . \quad$ Disponível em: < http://www.repositorio.jesuita.org.br/bitstream/handle/UNISINOS/4829/Lorena\%20Du 
arte\%20Santos\%20Lopes_.pdf?sequence=3\&isAllowed=y>. Acesso em: 21 dez. 2018, p. 03.

MAIA, Lorena Duarte Lopes. Colisão de direitos fundamentais: visão do Supremo Tribunal Federal. In: Âmbito Jurídico, Rio Grande, XV, n. 98, mar. 2012. Disponível: $<$ http://www.ambito-

juridico.com.br/site/index.php?n_link=revista_artigos_leitura\&artigo_id=11242>.

Acesso em: 21 dez. 2018.

MALUF, Adriana Caldas do Rego Freitas Dabus. Curso de Bioética e Biodireito. 3. ed. São Paulo: Atlas, 2015.

MARTÍNEZ, Gregorio Peces-Barba. Curso de Derechos Fundamentales. Teoria general. Madrid: Universidad Carlos III de Madrid, 1999.

MAZZUOLI, Valerio de Oliveira. Curso de Direitos Humanos. 5. ed. São Paulo: Método, 2018.

MELO, José Patrício Pereira. As diferenças entre o princípio da proporcionalidade, e o princípio da adequação e da concordância prática ou da harmonização. Revista direito e dialogicidade. v. 1, n. 1, p. 1-17, 2010.

MENDES, Gilmar Ferreira; BRANCO, Paulo Gustavo Gonet. Curso de Direito Constitucional. 13. ed. São Paulo: Saraiva, 2018.

MORAES, Alexandre de. Direitos humanos fundamentais - Teoria Geral. 9. ed., São Paulo: Atlas, 2011.

MOTTA, Sylvio. Direito constitucional. 27. ed. São Paulo: Método, 2018.

NUNES JÚNIOR, Flávio Martins Alves. Curso de direito constitucional. 2. ed. São Paulo: Revista dos Tribunais, 2017, p.

PAULO, Vicente; ALEXANDRINO, Marcelo. Direito constitucional descomplicado. 15. ed. São Paulo: Método. 2016. 
PECES-BARBA MARTÍNEZ, Gregorio. Curso de derechos fundamentales: teoría general. Madrid: Boletin Oficial del Estado, 1999.

PEREIRA, Jane Reis Gonçalves. Interpretação constitucional e direitos fundamentais: uma contribuição ao estudo das restrições aos direitos fundamentais na perspectiva da teoria dos princípios. Rio de Janeiro: Renovar, 2006.

RAMOS, André de Carvalho. Curso de direitos humanos. 5. ed., São Paulo: Saraiva, 2018.

SANTOS, Lília Nunes dos. Aborto: A atual discussão sobre a descriminalização do aborto no contexto de efetivação dos direitos humanos. Curitiba: Juruá, 2016.

SARLET, Ingo Wolfgang, Paulo. Curso de direito constitucional. 7. ed. rev., atual. e ampl. São Paulo: Malheiros, 1997. Apud Pedro Lenza. Direito Constitucional Esquematizado. 22. ed., São Paulo: Saraiva, 2018.

SILVA, José Afonso da. Curso de direito constitucional positivo. 37. ed. São Paulo: Malheiros, 2013.

SILVA, Virgílio Afonso da. O Proporcional e o Razoável. Revista dos Tribunais, n. 798, abr. 2002, p. 23-50, abr. 2002, p. 30.

SOUSA, Felipe Oliveira. O raciocínio jurídico entre princípios e regras. Revista de Informação Legislativa, Brasília a. 48 n. 192, p. 95-109, out./dez. 2011. Disponível em:

http://www2.senado.leg.br/bdsf/bitstream/handle/id/242932/000936212.pdf?sequenc e=3> Acesso em: 27 dez. 2018, p. 97.

STRECK, Lenio Luiz. Verdade e Consenso: constituição, hermenêutica e teorias discursivas; da possibilidade à necessidade de respostas corretas em direito. Rio de Janeiro: Lumen Juris, 2008. 
, Lenio Luiz. Hermenêutica Jurídica $\mathbf{e}(\mathrm{m})$ crise. 5. ed. Porto Alegre:

Livraria do Advogado, 2004.

ZAGREBELSKY, Gustavo. El derecho dúctil. Madrid: Trotta, 2007.

\section{APÊNDICE - REFERÊNCIAS DE NOTA DE RODAPÉ}

3. SILVA, José Afonso da. Curso de direito constitucional positivo. 37. ed. São Paulo: Malheiros, 2013, p. 178.

4. MAZZUOLI, Valerio de Oliveira. Curso de Direitos Humanos. 5. ed. São Paulo: Método, 2018, p.31.

5. SILVA, José Afonso da. Curso de direito constitucional positivo. 37. ed. São Paulo: Malheiros, 2013, p. 178.

6. MAZZUOLI, Valerio de Oliveira. Curso de Direitos Humanos. 5. ed. São Paulo: Método, 2018, p.31.

7. SARLET, Ingo Wolfgang. A eficácia dos direitos fundamentais. 11. ed. Porto Alegre: Livraria do Advogado, 2012, p. 17.

8. PECES-BARBA MARTÍNEZ, Gregorio. Curso de derechos fundamentales: teoría general. Madrid: Boletin Oficial del Estado, 1999, p. 37.

9. MARTÍNEZ, Gregorio Peces-Barba. Curso de Derechos Fundamentales. Teoria general. Madrid: Universidad Carlos III de Madrid, 1999, p. 109.

10. NUNES JÚNIOR, Flávio Martins Alves. Curso de direito constitucional. 2. ed. São Paulo: Revista dos Tribunais, 2017, p. 776-777.

11. HC № 93250, Segunda Turma, Tribunal Pleno (STF), Mato Grosso do Sul, Relator: Ellen Gracie, julgado em: 10-06-2008.

12. Ibidem, p.780-781. 
13. MORAES, Alexandre de. Direitos humanos fundamentais - Teoria Geral. $9^{a}$ ed., São Paulo: Atlas, 2011, p. 22.

14. SARLET, Ingo Wolfgang; MARINONI, Luiz Guilherme; MITIDIERO, Daniel. Curso de direito constitucional. 7. ed. São Paulo: Saraiva, 2018, p. 330.

15. RAMOS, André de Carvalho. Curso de direitos humanos. $5^{\text {a }}$ ed., São Paulo: Saraiva, 2018, p. 59.

16. LENZA, Pedro. Direito Constitucional Esquematizado. 22. ed. São Paulo: Saraiva, 2018, p. 1085.

17. MENDES, Gilmar Ferreira; BRANCO, Paulo Gustavo Gonet. Curso de Direito Constitucional. 13. ed. São Paulo: Saraiva, 2018, p. 201.

18. AGRA, Walber de Moura. Curso de Direito Constitucional. 9. ed. Belo Horizonte: Fórum, 2018, p. 188

19. BOBBIO, Norberto. A era dos direitos. Tradução de Carlos Nelson Coutinho, Rio de Janeiro: Campus, 2004, p. 09.

20. BONAVIDES, Paulo. Curso de direito constitucional. 7. ed. rev., atual. e ampl. São Paulo: Malheiros, 1997. Apud Pedro Lenza. Direito Constitucional Esquematizado. 22. ed., São Paulo: Saraiva, 2018, p. 1088.

21. Ibidem, p. 1088.

22. PAULO, Vicente; ALEXANDRINO, Marcelo. Direito constitucional descomplicado. 15. ed. São Paulo: Método. 2016, p. 56.

23. NUNES JÚNIOR, Flávio Martins Alves. Curso de direito constitucional. 2. ed. São Paulo: Revista dos Tribunais, 2017, p. 328.

24. LÉPORE, Paulo. Direito Constitucional - para os concursos de técnico e analista. 3. ed. Salvador: JusPodvm, 2015, p. 39. 
25. NUNES JÚNIOR, Flávio Martins Alves. Curso de direito constitucional. 2. ed. São Paulo: Revista dos Tribunais, 2017, p. 339.

26. LÉPORE, Paulo. Direito Constitucional - para os concursos de técnico e analista. 3. ed. Salvador: JusPodvm, 2015, p. 40.

27. NUNES JÚNIOR, Flávio Martins Alves. Curso de direito constitucional. 2. ed. São Paulo: Revista dos Tribunais, 2017, p. 344.

28. PUCCINELLI JÚNIOR, André. Curso de Direito constitucional. 2. ed. São Paulo: Saraiva, 2013, P. 116.

29. NUNES JÚNIOR, Flávio Martins Alves. Curso de direito constitucional. 2. ed. São Paulo: Revista dos Tribunais, 2017, p. 344.

30. MOTTA, Sylvio. Direito constitucional. 27. ed. São Paulo: Método, 2018, p. 110111.

31. SARLET, Ingo Wolfgang. MARINONI, Luiz Guilherme. MITIDIERO, Daniel. Curso de direito constitucional. $7^{a}$ ed., São Paulo: Saraiva, 2018, p 191.

32. AMARAL, Fernando. A distinção entre princípios e regras, a ordem Constitucional brasileira e a cidadania ecológica: uma proposta doutrinaria. Publica Direito. Disponível em <http://www.publicadireito.com.br/artigos/?cod=76a46a2fef5c9dd7>. Acesso em 17 nov. 2018.

33. SOUSA, Felipe Oliveira. O raciocínio jurídico entre princípios e regras. Revista de Informação Legislativa, Brasília a. 48 n. 192 out./dez. 2011. Disponível em: < https://www2.senado.leg.br/bdsf/bitstream/handle/id/242932/000936212.pdf?sequen ce $=3>$ Acesso em: 27 dez. 2018, p. 97.

34. STRECK, Lenio Luiz. Verdade e Consenso: constituição, hermenêutica e teorias discursivas; da possibilidade à necessidade de respostas corretas em direito. Rio de Janeiro: Lumen Juris, 2008, p. 250. 
35. DWORKIN, Ronald. Levando os direitos a sério. Tradução de Nelson Boeira. 1. ed. São Paulo: Martins Fontes, 2002, p. 39.

36. Ibidem, p. 39.

37. Ibidem, p. 42.

38. ALEXY, Robert. Teoria dos direitos fundamentais. Tradução de Virgílio Afonso da Silva, São Paulo: Malheiros, 2008, p. 90.

39. SOUSA, Felipe Oliveira. O raciocínio jurídico entre princípios e regras. Revista de Informação Legislativa, Brasília a. 48 n. 192 out./dez. 2011. Disponível em: < https://www2.senado.leg.br/bdsf/bitstream/handle/id/242932/000936212.pdf?sequen ce=3> Acesso em: 27 dez. 2018, p. 97.

40. ZAGREBELSKY, Gustavo. El derecho dúctil. Madrid: Trotta, 2007, p. 111.

41. MENDES, Gilmar Ferreira; BRANCO, Paulo Gustavo Gonet. Curso de Direito Constitucional. 13. ed. São Paulo: Saraiva, 2018, p. 109.

42. ALEXY, Robert. Teoria dos direitos fundamentais. Tradução de Virgílio Afonso da Silva, São Paulo: Malheiros, 2008, p. 141.

43. ALEXY, Robert. Teoría de los Derechos Fundamentales. Madrid: Centro de Estudios Constitucionales. 1993. p. 83.

44. FERRAZ JÚNIOR, Tércio Sampaio. Introdução ao Estudo do Direito: técnica, decisão, dominação. 2. ed. São Paulo: Atlas, 1994, p. 211.

45. Ibidem, p. 211.

46. DINIZ, Maria Helena. Conflito de Normas. 5. ed. São Paulo: Saraiva, 2005, p. 25.

47. Ibidem, p. 35.

48. Ibidem, p. 40. 
49. STRECK, Lenio Luiz. Hermenêutica Jurídica $\mathbf{e}(\mathbf{m})$ crise. 5. ed. Porto Alegre: Livraria do Advogado, 2004. p. 247

50. Ibidem, p. 247.

51. KÖHN, Edgar. Princípios e regras e sua identificação na visão de Robert Alexy. Boletim Jurídico, Uberaba/MG, a. 4, no 188. Disponível em $<$ https://www.boletimjuridico.com.br/doutrina/artigo/1440/principios-regrasidentificacao-visao-robert-alexy> Acesso em: 18 dez. 2018.

52. BANDEIRA DE MELLO, Celso Antônio. Curso de direito administrativo. São Paulo: Malheiros, 1999, p. 629.

53. BONAVIDES, Paulo. Curso de direito constitucional São Paulo: Malheiros, 1997, p. 279.

54. PEREIRA, Jane Reis Gonçalves. Interpretação constitucional e direitos fundamentais: uma contribuição ao estudo das restrições aos direitos fundamentais na perspectiva da teoria dos princípios. Rio de Janeiro: Renovar, 2006, p. 229.

55. ANDRADE, José Carlos Vieira de. Os Direitos Fundamentais na Constituição Portuguesa de 1976. Coimbra: Almedina, 1987, p. 220.

56. CANOTILHO, J. J. Gomes; MOREIRA, Vital. Fundamentos da Constituição. Coimbra: Coimbra, 1991, p. 135. Apud Edílson Pereira de Farias. Colisão de Direitos: A honra, a intimidade, a vida privada e a imagem versus a liberdade de expressão e informação. 2. ed. Porto Alegre: PC Editorial Ltda, 1996, p. 93.

57. FARIAS, Edílson Pereira de. Colisão de Direitos: A honra, a intimidade, a vida privada e a imagem versus a liberdade de expressão e informação. 2. ed. Porto Alegre: PC Editorial Ltda, 1996, p. 93. 
58. FARIAS, Edílson Pereira de. Colisão de Direitos: A honra, a intimidade, a vida privada e a imagem versus a liberdade de expressão e informação. 2. ed. Porto Alegre: PC Editorial Ltda, 1996, p. 94.

59. Ibidem, p. 98.

60. BARROSO, Luís Roberto. Interpretação e Aplicação da Constituição. 6‥ ed. rev., atual. e ampl.-São Paulo: Saraiva, 2004, p. 196.

61. FARIAS, Edílson Pereira de. Colisão de Direitos: A honra, a intimidade, a vida privada e a imagem versus a liberdade de expressão e informação. 2. ed. Porto Alegre: PC Editorial Ltda, 1996, p. 98.

62. GOMES CANOTILHO. J. J.. Direito Constitucional e Teoria da Constituição. 4. edição. Almedina. Coimbra. 2003., p. 1.188.

63. MELO, José Patrício Pereira. As diferenças entre o princípio da proporcionalidade, e o princípio da adequação e da concordância prática ou da harmonização. Revista direito e dialogicidade. v. 1, n. 1, p. 1-17, 2010.

64. FARIAS, Edílson Pereira de. Colisão de Direitos: A honra, a intimidade, a vida privada e a imagem versus a liberdade de expressão e informação. 2. ed. Porto Alegre: PC Editorial Ltda, 1996, p. 96.

65. DWORKIN, R. Levando os Direitos a Sério. Editora Martins Fontes. São Paulo, p. 127.

66. HORACIO, Lincoln. Distinção entre Princípios e Regras e Critérios de Ponderação em Caso de Conflitos Principiológicos. Conteúdo Jurídico, Brasília-DF: 09 mar. 2016. Disponível em: <http://www.conteudojuridico.com.br/?artigos\&ver=2.55392\&seo=1>. Acesso em: 19 dez. 2018.

67. ALEXY, Robert. Teoria dos direitos fundamentais. Tradução de Virgílio Afonso da Silva, São Paulo: Malheiros, 2008, p. 93-94. 
68. Ibidem, p. 95.

69. BARROSO, Luís Roberto. Colisão entre Liberdade de Expressão e Direitos da Personalidade. Critérios de Ponderação. Interpretação Constitucionalmente adequada do Código Civil e da Lei de Imprensa. Migalhas. Disponível em: <https://www.migalhas.com.br/arquivo_artigo/art_03-10-01.htm>. Acesso em 29 dez. 2018.

70. BUSTAMANTE, Thomas. Princípios, regras e conflitos normativos: uma nota sobre a superabilidade das regras jurídicas e as decisões contra legem. Disponível em: $<$ http://direitoestadosociedade.jur.pucrio.br/media/Artigo7\%20Thomas.pdf> Acesso em: 19 dez. 2018.

71. BARROSO, Luís Roberto. Colisão entre Liberdade de Expressão e Direitos da Personalidade. Critérios de Ponderação. Interpretação Constitucionalmente adequada do Código Civil e da Lei de Imprensa. Migalhas. Disponível em: <https://www.migalhas.com.br/arquivo_artigo/art_03-10-01.htm> Acesso em 19 dez. 2018.

72. Citação extraída do voto do Ministro Gilmar Mendes no HC 82.424, p.71.

73. ALEXY, Robert. Teoria dos direitos fundamentais. Tradução de Virgílio Afonso da Silva, São Paulo: Malheiros, 2008, p. 117-118.

74. CRISTÓVAM, José Sérgio da Silva. A resolução das colisões entre princípios constitucionais. Revista Jus Navigandi, ISSN 1518-4862, Teresina, ano 8, n. 62, 1 fev. 2003. Disponível em: <https://jus.com.br/artigos/3682>. Acesso em: 19 dez. 2018.

75. DAMACENO, Gian Carlos. Há colisão de direitos fundamentais? Revista Jus.com, Brasília-DF, 10 out. 2014. Disponível em: < https://jus.com.br/artigos/32635/ha-colisao-de-direitos-fundamentais>. Acesso em: 19 dez. 2018. 
76. MENDES, Gilmar Ferreira; BRANCO, Paulo Gustavo Gonet. Curso de Direito Constitucional. 13. ed. São Paulo: Saraiva, 2018, p. 366.

77. SARLET, Ingo Wolfgang,, Paulo. Curso de direito constitucional. 7. ed. rev., atual. e ampl. São Paulo: Malheiros, 1997. Apud Pedro Lenza. Direito Constitucional Esquematizado. 22. ed., São Paulo: Saraiva, 2018, p. 1088.

78. SILVA, Virgílio Afonso da. O Proporcional e o Razoável. Revista dos Tribunais, n. 798 , abr. 2002, p. 23-50, abr. 2002, p. 30.

79. SILVA, José Afonso. Curso de Direito Constitucional Positivo. 14. ed. São Paulo: Malheiros, 2001, p. 244-245.

80. SARLET, Ingo Wolfgang. Dignidade da pessoa humana e direitos fundamentais. 2. ed. rev. e amp. Porto Alegre: Livraria do Advogado, 2002, p. 60

81. BRASIL. Constituição (1988). Constituição da República Federativa do Brasil de 1988: promulgada em 05 de outubro de 1888. Disponível em <http://www.planalto.gov.br/ccivil_03/Constituicao/Constituicao.htm>. Acesso em: 29 dez. 2018.

82. SARLET, Ingo Wolfgang. Dignidade da pessoa humana e direitos fundamentais. 11. ed. Porto Alegre: Livraria do Advogado, 2011, p. 80.

83. BRASIL. Superior Tribunal de Justiça. STF nega Habeas Corpus a editor de livros condenado por racismo contra judeus, Brasília, DF, 17 set. 2003. Disponível em: <http://twixar.me/xkS3>. Acesso em: 22 dez.

84. BRASIL. Superior Tribunal de Justiça. STF nega Habeas Corpus a editor de livros condenado por racismo contra judeus, Brasília, DF, 17 set. 2003. Disponível em: <http://twixar.me/xkS3>. Acesso em: 22 dez.

85. JÚNIOR OLIVEIRA, Juarez Monteiro de. O habeas corpus 82.424-2 e a construção dos conceitos de liberdade de expressão e dignidade da pessoa. In: XVIII 
Congresso Nacional do CONPEDI, São Paulo/SP: 04, 05, 06 e 07 nov. 2009. Disponível em: <http://twixar.me/2kS3>. Acesso em: 22 dez. 2018. p. 04.

86. BRASIL. Superior Tribunal de Justiça. STF nega Habeas Corpus a editor de livros condenado por racismo contra judeus, Brasília, DF, 17 set. 2003. Disponível em: <http://twixar.me/kkS3>. Acesso em: 22 dez.

87. BRASIL. Superior Tribunal Federal. Habeas Corpus n.o 82.424-RS. Relator Moreira Alves, Brasília, DF, 17 set. 2003. Disponível em: <http://twixar.me/kkS3>. Acesso em: 23 dez. p. 134-135.

88. BRASIL. Superior Tribunal Federal. Habeas Corpus n. 82.424-RS. Relator Moreira Alves, Brasília, DF, 17 set. 2003. Disponível em: <http:/twixar.me/kkS3>. Acesso em: 23 dez. p. 166.

89. Ibidem, p. 203.

90. Ibidem, p. 362.

91. BRASIL. Superior Tribunal Federal. Habeas Corpus n. 82.424-RS. Relator Moreira Alves, Brasília, DF, 17 set. 2003. Disponível em: <http:/twixar.me/kkS3>. Acesso em: 23 dez. p. 631.

92. LOPES, Lorena Duarte Santos. A (in)adequada recepção da ponderação alexyana pelo direito brasileiro. Repositório digital da Biblioteca da Unisinos. São Leopoldo/RS. 12 dez. 2014. Disponível em: <http://twixar.me/qkS3>. Acesso em: 21 dez. 2018, p. 03.

93. JÚNIOR OLIVEIRA, Juarez Monteiro de. O habeas corpus 82.424-2 e a construção dos conceitos de liberdade de expressão e dignidade da pessoa. In: XVIII Congresso Nacional do CONPEDI, São Paulo/SP: 04, 05, 06 e 07 nov. 2009. Disponível em: <http://twixar.me/rkS3>. Acesso em: 21 dez. 2018. p. 03. 
94. BRASIL. Superior Tribunal Federal. Habeas Corpus n. 71373-4-RS. Relator Francisco Rezek, Brasília, DF, 10 nov. 1994. Disponível em: <http://twixar.me/rkS3>. Acesso em: 24 dez., p. 01-02.

95. Ibidem, p. 13.

96. MAIA, Lorena Duarte Lopes. Colisão de direitos fundamentais: visão do Supremo Tribunal Federal. In: Âmbito Jurídico, Rio Grande, XV, n. 98, mar. 2012. Disponível: $<$ http://www.ambito-

juridico.com.br/site/index.php?n_link=revista_artigos_leitura\&artigo_id=11242>. Acesso em: 21 dez. 2018.

97. CRISTÓVAM, José Sérgio da Silva. A resolução das colisões entre princípios constitucionais. Revista Jus Navigandi, ISSN 1518-4862, Teresina, ano 8, n. 62, 1 fev. 2003. Disponível em: <https://jus.com.br/artigos/3682>. Acesso em: 21 dez. 2018, p. 03.

98. BRASIL. Superior Tribunal Federal. Habeas Corpus n. 71373-4-RS. Relator Francisco Rezek, Brasília, DF, 10 nov. 1994. Disponível em: <http://twixar.me/rkS3>. Acesso em: 24 dez. 2018.

99. MALUF, Adriana Caldas do Rego Freitas Dabus. Curso de Bioética e Biodireito. 3. ed. São Paulo: Atlas, 2015, p. 276-277.

100. SANTOS, Lília Nunes dos. Aborto: A atual discussão sobre a descriminalização do aborto no contexto de efetivação dos direitos humanos. Curitiba: Juruá, 2016. 372 p. 194.

101. SANTOS, Lília Nunes dos. Aborto: A atual discussão sobre a descriminalização do aborto no contexto de efetivação dos direitos humanos. Curitiba: Juruá, 2016, p. 284.

102. DINIZ, Maria Helena. O Estado Atual do Biodireito. 9. ed. São Paulo: Saraiva, 2014, p. 76. 
103. BRASIL. Superior Tribunal Federal. Arguição de descumprimento de preceito fundamental n. 54-DF. Relator Ministro Marco Aurélio, Brasília, DF, 12 abr. 2012. Disponível em:

http://redir.stf.jus.br/paginadorpub/paginador.jsp?docTP=TP\&docID=3707334 >. Acesso em: 26 dez. 2018, p. 68.

104. Ibidem, p. 124.

105. Ibidem, p. 136.

106. BRASIL. Superior Tribunal Federal. Arguição de descumprimento de preceito fundamental n. 54-DF. Relator Ministro Marco Aurélio, Brasília, DF, 12 abr. 2012. Disponível em:

http://redir.stf.jus.br/paginadorpub/paginador.jsp?docTP=TP\&docID=3707334>. Acesso em: 26 dez. 2018, p. 181.

Enviado: Fevereiro, 2019.

Aprovado: Junho, 2020. 